University of Florida Levin College of Law

UF Law Scholarship Repository

Faculty Publications

Faculty Scholarship

$4-1-2005$

\title{
The Birth of a "Logical System": Thurman Arnold and the Making of Modern Administrative Law
}

Mark Fenster

University of Florida Levin College of Law, fenster@law.ufl.edu

Follow this and additional works at: http://scholarship.law.ufl.edu/facultypub

Part of the Administrative Law Commons

\section{Recommended Citation}

Mark Fenster, The Birth of a "Logical System": Thurman Arnold and the Making of Modern Administrative Law, 84 Or. L. Rev. 69 (2005), available at http://scholarship.law.ufl.edu/facultypub/65

This Article is brought to you for free and open access by the Faculty Scholarship at UF Law Scholarship Repository. It has been accepted for inclusion in Faculty Publications by an authorized administrator of UF Law Scholarship Repository. For more information, please contact outler@law.ufl.edu. 


\section{The Birth of a "Logical System": Thurman Arnold and the Making of Modern Administrative Law}

Huge treatises are now appearing showing the compatibility of administrative justice with the law. Just as theology was not able to exist without a Redeemer, so the "law" must have its equity or its administrative law in order to save mankind from the consequences of its logical systems.

$$
\text { - Thurman Arnold (1935) }{ }^{1}
$$

he practice, teaching, and study of modern administrative
law have developed in the midst of academic debates over
how to resolve conflicts between a dominant set of legal doc-
trines and external political demands. Periodic administrative le-
gitimacy crises have spawned an academic literature consisting of
authoritative, influential articles and books that attempt to clarify
nascent doctrines and theories. ${ }^{2}$ The now-familiar rhythm of

* Associate Professor, Levin College of Law, University of Florida. Thanks to my colleagues Lyrissa Lidsky and Bill Page, and to Tom Cotter, Jack Schlegel, and Trysh Travis for comments. Thanks also to the American Heritage Center at the University of Wyoming for assistance with the Arnold papers; to Rick Donnelly, Ron Perry, and Christopher Vallandingham of the University of Florida Law Library for help in tracking down sources; and to research funding from the Levin College of Law.

1 Thurman W. Arnold, The Symbols of Government 64 (1935) [hereinafter SYMBOLs].

2 The period of greatest ferment was the mid-1970s, when three influential critiques of administrative law appeared: James O. Freedman, Crisis and Legitimacy in the Administrative Process, 27 STAN. L. Rev. 1041 (1975); Robert L. Rabin, Administrative Law in Transition: A Discipline in Search of an Organizing Principle, 72 Nw. U. L. Rev. 120 (1977); Richard B. Stewart, The Reformation of American Administrative Law, 88 HARV. L. Rev. 1668 (1975). This ferment was neither unprecedented, see Henry J. Friendly, The Federal Administrative Agencies: The Need for Better Definition of Standards (1962), nor the last word, see Christopher F. Edley, Jr., Administrative Law: Rethinking Judicial Control of Bureaucracy (1990); Jody Freeman, The Private Role in Public Governance, 75 N.Y.U. L. Rev. 543, 545-49 (2000). 
such outbursts began with modern administrative law's widespread emergence in the 1930 s, when federal regulatory agencies became sufficiently prevalent to warrant extensive attention from legal academics. ${ }^{3}$ Administrative law histories have established this fairly well-known story: academics sympathetic to the Roosevelt Administration, including, most prominently, Felix Frankfurter and the young professors who had taken his classes at Harvard Law School, provided the theoretical and doctrinal bases for the Administration's efforts to address the vast economic and social crises wrought by the Depression. ${ }^{4}$ In doing so, this first generation of scholars launched administrative law as a basic part of the law school curriculum and a popular subject of academic legal research. More important, they put in place a particular ideological and conceptual approach to the subject, one that continues to shape the theory and practice of administrative law today. ${ }^{5}$ For first-generation administrative law scholars, the correct legal and administrative processes and structure would lead inexorably to superior law and policies. Their presumptions about both the peculiar competencies of administrative agencies and the limited but still important role of judicial review of agency action continue to underpin the conceptual dimensions of the field and the logic of legal doctrine.

These scholars faced opposition in their own time, most famously from elite members of the legal community who-hoping to protect their clients, their status and business, and/or their legal culture-sought to challenge the political and legal legitimacy of new and expanded federal regulatory programs. ${ }^{6}$ But they also faced a critique from an unlikely source within the legal

${ }^{3}$ See Robert L. Rabin, Federal Regulation in Historical Perspective, 38 STAN. L. REv. 1189, 1252-53 (1986).

4 See, e.g., Stephen G. Breyer et al., Administrative Law and Regulatory Policy: Problems, Text, and Cases 21-24 (5th ed. 2002); G. Edward White, The Constitution and the New Deal 103-08, 114-16 (2000).

5 See William C. Chase, The American Law School and the Rise of Ad. ministrative Government (1982); Morton J. Horwitz, The Transformation of American Law, 1870-1960: The Crisis of Legal Orthodoxy 213-25 (1992); WHITE, supra note 4, at 103-08; Thomas O. Sargentich, Teaching Administrative Law in the Twenty-First Century, 1 WIDENER J. PuB. L. 147, 150-54 (1992); Stewart, supra note 2, at 1677-78.

6 See Ronen Shamir, Managing Legal Uncertainty: Elite Lawyers in the New Deal (1995); George B. Shepherd, Fierce Compromise: The Administrative Procedure Act Emerges from New Deal Politics, 90 Nw. U. L. Rev. 1557, 1571-72 (1996); Nicholas S. Zeppos, The Legal Profession and the Development of Administrative Law, 72 Chi.-Kent L. Rev. 1119 (1997). 
academy: Thurman Arnold, a Yale Law School faculty member associated with the legal realists. ${ }^{7}$ Like the first generation of administrative law scholars, Arnold was an advocate of federal regulation (especially that introduced as part of the New Deal), but unlike his contemporaries at Harvard, he was deeply suspicious of comprehensive solutions based on structural and procedural systems. ${ }^{8}$ His brief but evocative writings on the subject represent a singular effort to bring realism's insights to the judicial review of federal administrative agencies. ${ }^{9}$ Arnold argued that society is shaped by a deep-seated desire for stable and authoritative legal and political symbols, and he proposed an eclectic mix of creative means to enable the growth of an administrative state that would be sufficiently free of legal constraints to attack what he considered the root causes of the Depression.

Both early proponents of the federal administrative state and their critics shared the assumption that the "supremacy of law" undergirding a liberal democracy required the judiciary and administrative agencies to operate within separate but interdependent spheres-even if they disagreed as to whether the judiciary's role was to uphold or strike down agency decisions. ${ }^{10}$ By contrast, Arnold called for abandoning the separate domains of agency regulation and judicial review in favor of more functional, flexible relationships between courts and agencies, which

${ }^{7}$ The best current source of biographical information on Arnold is Gene M. Gressley, Introduction to Voltaire and THE Cowboy: The Letters of Thurman Arnold 1 (Gene M. Gressley ed., 1977) [hereinafter Voltaire and THE CowBoY]. A full-length biography by Spencer Webber Waller is forthcoming from NYU Press. Spencer Weber Waller, Thurman Arnold: A Biography (forthcoming 2005).

8 Mark Fenster, The Symbols of Governance: Thurman Arnold and Post-Realist Legal Theory, 51 Buff. L. Rev. 1053, 1069-72 (2003).

9 See Jerry L. Mashaw, Bureaucratic Justice: Managing Social SecurITY Claims 11-14 (1983).

10 The popular notion of "judicial supremacy," which presumes the judiciary's authority to provide a final review of legal and especially constitutional questions, became prominent during the 1890 s with the early stirrings of the administrative state and was tied during that time to classical legal formalism and laissez faire ideology. See Robert A. Burt, The Constitution in Conflict 232-53 (1992); Stephen Skowronek, Building a New American State: The Expansion of National Administrative Capacities, 1877-1920, at 152-53 (1982); William E. Nelson, Changing Conceptions of Judicial Review: The Evolution of Constitutional Theory in the States: 1790-1860, 120 U. PA. L. REv. 1166, 1182-85 (1972); $c f$. Barry Friedman, The History of the Countermajoritarian Difficulty, Part One: The Road to Judicial Supremacy, 73 N.Y.U. L. Rev. 333, 339-42 (1998) (placing the term's earliest rise in popularity in the early and mid-nineteenth century). 
would include both institutional partnerships and greater agency independence. This departure from the consensus of his day reflected Arnold's commitment to two of realism's core tendencies: a deep-rooted distrust of formal distinctions and a restless quest for practical solutions to the functional impasses caused by unreflective formalist assumptions. ${ }^{11}$ The solutions Arnold proposed to the inefficiencies and irrationalities caused by judicial review were thus both critical and reconstructive, and they opposed the formalities of legal system-building. ${ }^{12}$

Arnold resisted the imposition of an overly logical system onto administrative law that would place judicial review at its core, even as he recognized that the judiciary was a necessary, if merely symbolic and ideological, component of the modern administrative state. Like the first-generation scholars and their critics, Arnold also saw the inevitability of the judiciary's institutional "supremacy," but he assumed that any effort to retain judicial review would inevitably sink agency discretion. In the "trial by combat" of litigation, courts would always emerge as the symbolic superior to any party appearing before them, whether it be an individual, an agency, or even Congress. ${ }^{13}$ For Arnold, the only way to protect fledgling administrative agencies, therefore, was to allow them to avoid the combat in any way possible and to reconceptualize administrative law as akin to the law of equitya flexible means of providing the imprimatur of legal legitimacy that could avoid the unforeseen, foolish consequences of a logical system of legal doctrine.

Arnold's proposed alternatives to trial by combat were dead on arrival, and his critique of administrative law has largely been ignored, even as his antiformalist criticism has remained current

11 The "functionalism" to which Arnold and the legal realists ascribed sought to understand law "in terms of [law's] factual context and economic and social consequences" and to find, explain, and make law relevant to realities that lurked in the knowable world rather than within the formal categories on which classical legal formalism focused. Laura Kalman, Legal Realism at Yale, 1927-60, at 3 (1986). More specifically, it both assumed the inherent superiority of the modern liberal capitalism toward which Western societies had presumably been evolving, and sought to hasten that evolution. See Robert W. Gordon, Critical Legal Histories, 36 STAN. L. Rev. 57, 159 (1984).

12 This antisystemic tendency extended to sarcastic criticism of the American Law Institute's common law Restatement project. See Thurman Arnold, The Restatement of the Law of Trusts, 31 Colum. L. Rev. 800 (1931).

13 See Thurman W. Arnold, Trial by Combat and the New Deal, 47 Harv. L. Rev. 913 (1934) [hereinafter Trial by Combat]. 
and popular. ${ }^{14}$ But his work was more than a historical anomaly. It was prophetic. He saw that the emerging approach advocated by his contemporaries featured a comprehensive, formal system that would successfully use prevailing symbols to legitimate administrative agencies. He also predicted the costs of creating a formal structure that would ultimately limit administrative discretion and regulatory flexibility. Equally significant, his work illuminates two fundamental, related, and relatively unexplored aspects of the past and present of administrative law-aspects which in turn explain the cyclical tendencies of scholars in the field to find crisis and resolution in its familiar and flexible structures.

First, Arnold's critique and the debate it sparked between himself and Felix Frankfurter starkly reveals modern administrative law's procedural core and its precursor relationship to the legal process theory that would become the dominant postrealist approach to legal scholarship and teaching in the postwar period. Arnold rejected any fundamental or functional distinctions between the judiciary and agencies as institutions of governance except insofar as they served the symbolic dimensions of governance. He also showed little faith in process as a necessary and sufficient means to a functional administrative state. Rather, he saw procedural doctrines in the same way that a wily, creative attorney does: as a tool to move a decision maker to a desired outcome. Process, form, and structure were secondary to substantive policy and functional results.

It was in response to Arnold as well as to opponents of the New Deal's expansion of the regulatory state that first-generation scholars began to articulate concepts of process-centered jurisprudence, limited, reasoned judicial review, and institutional competencies-concepts now associated with the legal process theory-as justifications both for the rise of administrative agencies and for the continuing (though limited) importance of judicial review of agency action. Juxtaposing the first-generation scholars' work to Arnold's critique, then, makes plain the core commitments of modern administrative law-both in the moment at which the first-generation scholars emerged and in the later appearance and success of legal process theory. In this light, administrative law appears less a realist effort to create a pragmatic, problem-solving legal regime and academic discipline

${ }^{14}$ See Fenster, supra note 8, at 1056-57. 
and more a traditional effort to apply recognizable, comprehensive, formal legal structures and methods to an emergent area of law and government.

Second, reinserting Arnold's critique into the historical trajectory of administrative law enables a better understanding of how the first-generation scholars set in motion a systematic approach that is sufficiently abstract, flexible, comprehensive, and familiar to have contained the political and conceptual challenges to the administrative state that have unfolded over the past fifty years. Although first-generation scholars recognized the dangers of judicial review for administrative agencies-this debate took place, after all, at the height of the controversy surrounding the Supreme Court's finding some New Deal regulatory programs unconstitutional - they advocated a system based on the judiciary's ultimate supremacy over agency competence in developing expert policy. For more than sixty years, and despite the numerous crises of faith in the various institutions and legal doctrines that compose the logical system of administrative law, the system has survived. New administrative law reforms and developments have reaffirmed an earlier faith in a structural solution to the challenge of the regulatory state-a solution based on administrative and legal processes and overseen ultimately by the judiciary. As with Arnold's critique, more recent scholarship has sought to challenge the first generation's model, often borrowing methods and theories offered by other academic disciplines. In doing so, this scholarship faces the same conceptual impasse and settled institutions and doctrines that Arnold faced; moreover, this impasse and these settlements have been further calcified by the field's long history.

To illuminate the comparison between Arnold and the consensus on administrative law that emerged in the 1920s and 1930s, this Article begins in Part I by describing first-generation scholars' successful efforts to legitimate a vision of agency expertise and judicial review. Part II turns to Arnold's competing vision of administrative law, first summarizing the broad themes of his approach to law and governance and then focusing on his critique of conventional notions of judicial review within administrative law and his various proposals for a less formal and more flexible approach. Part III discusses the first-generation scholars' debate with Arnold in correspondence and published scholarship-a debate that illuminates what both sides saw as the stakes of their 
proposed visions of modern administrative law. Parts IV and V consider the implications of this debate for the historiography of administrative law as a field of legal academic endeavor. Part IV demonstrates the conceptual connections between first-generation scholarship and the legal process theory that emerged in the postwar period and recounts Arnold's intervention in 1960 against what he saw as legal process advocates' conservative formalism-an intervention in which he revisited the arguments that he initially made as modern administrative law emerged. Part V considers the continuities between first-generation scholarship and more recent administrative law doctrine and scholarship, as well as the continuities between Arnold's dissent and current critiques of the field.

\section{I}

An Administrative and Judicial Process: First-Generation Administrative LAW SCHOLARSHIP

At the height of legal realism during the $1920 \mathrm{~s}$ and $1930 \mathrm{~s},{ }^{15}$ administrative law was both a nascent academic enterprise and an embryonic practice area of federal law. ${ }^{16}$ Significant federal statutory mandates for regulatory programs whose implementation was overseen by administrative agencies (as well as myriad state regulatory agencies overseeing state programs) had been in place since the late nineteenth century during the Populist and Progressive Eras. ${ }^{17}$ Nevertheless, the modern federal administrative state-envisioned as a response to and check on the destructive consequences of capitalism-did not begin in earnest until the early New Deal. ${ }^{18}$ Unsurprisingly, then, as late as 1937, only a bare majority of accredited law schools offered one or more courses in administrative law. ${ }^{19}$ And even though numerous important agencies, including the Interstate Commerce Commission and the Federal Trade Commission, had fully established

\footnotetext{
15 See Kalman, supra note 11 , at 3.

16 See A.H. Feller, Prospectus for the Further Study of Federal Administrative Law, 47 YALE L.J. 647 (1938).

17 See William J. Novak, The People's Welfare: Law and Regulation in Nineteenth-Century America (1996); Robert H. Wiebe, The Search for OrDER, 1877-1920 (1967).

18 See Rabin, supra note 3, at 1243-53.

19 See Arthur T. Vanderbilt, The Bar and the Public, 23 A.B.A. J. 871, 874 (1937).
} 
themselves by the time of the New Deal, ${ }^{20}$ the Roosevelt Administration faced enormous resistance from elite segments of the legal profession as it attempted to expand the size and scope of the federal regulatory bureaucracy. ${ }^{21}$ Attorneys and jurists increasingly accepted federal administrative agencies as essential elements of American governance during the early part of the twentieth century despite the agencies' apparently anomalous position within traditional, formalist conceptions of the constitutional order. But their acceptance was grudging, and the legal legitimacy of the administrative state and its operations remained the subject of vigorous debate. ${ }^{22}$

\section{A. Precursors to the First Generation}

Legal academics in the early twentieth century had developed a number of competing approaches to administrative law. Each approach shared the general commitment of the Progressive Era to address large scale economic and social issues through legislative regulatory programs administered by government bureaucracies rather than through common law causes of action adjudicated by courts. Writing in the Harvard Law Review in 1936, Justice Harlan Fiske Stone described this shift as "a substitution made necessary, not by want of an applicable law, but because the ever expanding activities of government in dealing with the complexities of modern life had made indispensable the adoption of procedures more expeditious and better guided by specialized experience than any which the courts had provided." 23

\footnotetext{
20 See Interstate Commerce Act of 1887, ch. 104, 24 Stat. 379, 383 (codified as amended in scattered sections of 49 U.S.C.) (establishing Interstate Commerce Commission); Federal Trade Commission Act of 1914, ch. 311, 38 Stat. 717 (codified as amended at 15 U.S.C. $\$ \S 41-58(2000)$ ) (establishing Federal Trade Commission). See WHITE, supra note 4, at 98-103 (describing how administrative agencies such as the Interstate Commerce Commission had grown in power and achieved some measure of popular and judicial acceptance during the early part of the twentieth century).

21 See sources cited supra note 6.

22 See WHITE, supra note 4, at 96-108.

23 Harlan F. Stone, The Common Law in the United States, 50 Harv. L. Rev. 4, 16 (1936). On Progressive Era political commitments and their relationship to academics studying government and administrative law, see JAMES T. KLOPPENBERG, UnCertain Victory: Social Democracy and Progressivism in European AND American Thought, 1870-1920, at 361-63, 383-85 (1986). See also William J. Novak, The Legal Origins of the Modern American State, in LoOKING BACK AT Law's Century 249 (Austin Sarat et al. eds., 2002).
} 
The least important of these approaches within law schools was that associated with Frank Goodnow, a member of Columbia University's Law School and Government Department. Goodnow was a leading Progressive advocate of administrative agencies and was the teacher of the first administrative law course taught in a law school. ${ }^{24}$ Goodnow's legal scholarship sought to enable regulatory bodies to operate free of the narrow constitutional constraints that courts used to limit congressional legislation and delegation. ${ }^{25}$ His approach was largely an internal one that studied how administrative officers applied and executed statutes, and he focused less on common law development by the judiciary, which was the traditional focus of the legal academy. ${ }^{26}$ Goodnow ultimately became better known as a founder of the academic study of administration and politics in political science and government departments within the social sciences and for developing the empirical study of government institutions. ${ }^{27}$

A second approach that was more cognizable and much betterknown within the legal academia of the 1920s and 1930s was developed by Ernst Freund. Like Goodnow, Freund had worked in law schools and political science departments and had served in government agencies. ${ }^{28}$ Freund also shared with Goodnow a

24 See Dorothy Ross, The Origins of American Social Science (1991); Richard M. Thomas, Deprofessionalization and the Postmodern State of Administrative Law Pedagogy, 42 J. Legal Educ. 75, 75 n.6 (1992).

25 See Novak, supra note 23, at 271-72.

26 Goodnow's most significant treatise on administrative law was intended for students of "politics." Frank J. Goodnow, The Principles of the Administrative LAw OF THE UNITED STATES, at iv (1905). The treatise spent only the first of its six "books" and part of another (in all, less than a third of its pages) on specifically legal issues, concentrating instead on the forms and practices of administration and the work of administrative officers. See also John A. Fairlie, Public Administration and Administrative Law, in Essays on the Law and Practice of Governmental Administration: A Volume in Honor of Frank Johnson Goodnow 3, 28-30 (Charles G. Haines \& Marshall E. Dimock eds., 1935) (contrasting Goodnow's approach to the more legal approaches of Ernst Freund, Bruce Wyman, and others within legal academia). An illustration of Goodnow's distance from the traditional legal academy is the apocryphal tale of Thomas Reed Powell, who described the experience of studying under Goodnow in the early years of the twentieth century after having attended Harvard Law School as one in which he had been "deHarvardized." Kalman, supra note 11, at 50.

27 See James Hart, An Introduction to Administrative Law 4-5 (1940); Introduction, in Essays on the Law and Practice of Governmental AdminisTRATION, supra note 26, at $\mathrm{v}, \mathrm{x}$.

28 See Oscar Kraines, The World and Ideas of Ernst Freund 2-8 (1974). On the importance of Goodnow's work to the development of a pre-New Deal public law, see Novak, supra note 23, at 255. 
commitment to Progressive politics, as Freund called for both increased governmental reliance on technical, scientific professionals to make expert administrative decisions divorced from the corruption of politics and for a field of administrative law to legitimate and assist in the "legislative regulation of economic activity." 29 He explicitly encouraged legal academics to study administrative agencies and to assist them in discerning and meeting their broad legislative mandates. ${ }^{30}$

Freund focused especially on systems of public administration, on the specific powers that public officers and agencies wielded (such as licensing and ratemaking), and on statutory and common law bases for judicial review of administrative action. ${ }^{31}$ As Freund explained, studying judicial review constituted a "strictly legal discipline" and had become the subject matter of the legal academy; public administration, by contrast, was an extralegal realm considered by government and political science professors. ${ }^{32}$ In this regard, he sought to bridge what he saw as the differentiated study of administrative organization and administrative powers, the former of which focused on optimizing internal public administration and the latter of which performed the "more strictly legal" task of protecting "right and justice" through external judicial institutions. ${ }^{33}$ In his classroom instruction on the internal functions of administrative agencies, Freund's work focused students' attention on the workaday world of government officials and attorneys and served the traditional role of introducing "the rank and file of the bar-to-be to methods of legal thinking, to the fundamental rules, [and] to the elements of procedure." 34 This approach remained an important one to the legal academy and to the bar, as faculty focused on the

29 Ernst Freund, Historical Survey, in The Growth of AMERICAN Administra. TIVE LAW 9, 20 (1923). Freund's approach itself had its precedents; treatise author and state supreme court justice Thomas Cooley, for example, was a nineteenth century precursor of Freund. See Paul D. Carrington, Law and Economics in the Creation of Federal Administrative Law: Thomas Cooley, Elder to the Republic, 83 IowA L. REV. 363, 387-88 (1998).

30 See Ernst Freund, The Correlation of Work for Higher Degrees in Graduate Schools and Law Schools, 11 ILL. L. REv. 301, 308 (1916).

31 See Oliver P. Field, The Study of Administrative Law: A Review and a Proposal, 18 Iowa L. REv. 233, 234-35 (1933).

32 Ernst Freund, Administrative Law, 1 Encyclopaedia of THE Social ScIENCES 452, 455 (Edwin R. A. Seligman ed., 1932).

33 Id.

34 Maurice H. Merrill, Three Possible Approaches to the Study of Administrative Law, 18 Iowa L. Rev. 228, 232 (1933). 
vocational aspects of administrative law through the case method, ${ }^{35}$ and as leading members of the bar called for greater attention in law teaching to "the principles and methods of procedure in administrative law cases" within agencies. ${ }^{36}$

In his more traditional legal academic work, Freund presented a curiously conservative approach for a committed Progressive. ${ }^{37}$ His early casebook on administrative law used case-based training methods to emphasize the various common law means by which individuals could seek relief from judicial action. ${ }^{38}$ But his understanding of the constitutional and legislative limits of administrative agencies was quite constrained. To Freund, legislatures strictly limited agency discretion within a statutory framework, and any agency's efforts to regulate beyond its statutory mandate that affected individual liberty or property rights was "hardly conformable to the "Rule of Law." 39 At the same time, he considered it appropriate for legislatures to delegate limited agency authority to implement uncontroverted issues of policy or opinion. ${ }^{40}$ In the absence of such consensus, Freund argued, legislatures should control private activity directly by statute without administrative enforcement. ${ }^{41}$

\footnotetext{
35 See Field, supra note 31, at 235; Paul L. Sayre, A Common Law of Administrative Powers, 18 Iowa L. Rev. 241, 247 (1933). After Freund's death, his successor at the University of Chicago, Kenneth Sears, published a similar casebook that provided a remedy-based, functional approach and limited consideration of the larger constitutional issues on which later legal academic casebooks written or influenced by Felix Frankfurter focused. See Kenneth C. Sears, Cases and Materials on Administrative Law at vii-viii (Warren A. Seavey ed., 1938); infra notes 69-72 and accompanying text.

36 O. R. McGuire, Reforms Needed in the Teaching of Administrative Law, 6 GEO. WASH. L. Rev. 171, 178 (1938). During this period, McGuire was chairman of the ABA's Special Committee on Administrative Law, which was developing a proposal for a specialized administrative court to hear appeals from agency adjudications. See Daniel R. Ernst, Dicey's Disciple on the D.C. Circuit: Judge Harold Stephens and Administrative Law Reform, 1933-1940, 90 Geo. L.J. 787, 790-93 (2002).

37 Freund's commitment to Progressivism was real but cautious. See Kraines, supra note 28 , at 93-94.

38 See Merrill, supra note 34, at 228; Fairlie, supra note 26, at 28-29.

${ }^{39}$ Freund, supra note 29, at 22-23; see also Ernst Freund, The Substitution of Rule for Discretion in Public Law, 9 Am. Pol. SCI. Rev. 666, 670 (1915) ("[F]or in a government by law discretion ought to have a very limited place in administration."). Freund's position was subject to vigorous criticism from, among others, Dean John Wigmore of Northwestern. See generally John H. Wigmore, The Dangers of Administrative Discretion, 19 ILl. L. Rev. 440, 441 (1925) (arguing for control rather than reduction of administrative discretion).

40 See Ernst Freund, Administrative Powers Over Persons and Property 218-221 (1928).

41 See id.
} 


\section{B. The First Generation}

Established at Harvard in the century's first decade, the approach that began to dominate legal academia during the early twentieth century opposed Freund's narrow vision of administrative discretion and his emphasis on the judicial review of statutory and common law issues and instead focused more narrowly than Goodnow on the issues relating to judicial review. ${ }^{42}$ In the first quarter of the century, Harvard Law School Dean Roscoe Pound, Harvard professors Bruce Wyman and Thomas Reed Powell, ${ }^{43}$ and, later and more clearly, Harvard professor Felix Frankfurter and his students were predominant among the leading legal academic theorists who helped develop the most influential modern conception of administrative law. ${ }^{44}$ With

42 See White, supra note 4, at 107; $c f$. Chase, supra note 5, at 106-15 (alleging that Frankfurter, with the help of his students, purposefully subverted Freund's approach and, to an extent, his career).

43 See Bruce Wyman, Principles of Administrative Law (1903); Roscoe Pound, Executive Justice, 46 AM. L. REG. 137 (1907); Roscoe Pound, The Growth of Administrative Justice, 2 WIS. L. REV. 321 (1924) [hereinafter Pound, Growth]; Thomas Reed Powell, Administrative Exercise of the Police Power, 24 HARv. L. Rev. 268 (1910); Thomas Reed Powell, Administrative Exercise of the Police Power [Continued], 24 Harv. L. REv. 333 (1910). Pound would later adamantly oppose the New Deal and administrative discretion, and he singled out first-generation scholars for withering, often excessive criticism. See Paul R. Verkuil, The Emerging Concept of Administrative Procedure, 78 Colum. L. REv. 258, 268-71 (1978).

44 See Sayre, supra note 35, at 241-42 (describing Frankfurter's influence on the then-present generation of legal academics teaching and writing on administrative law). On Frankfurter's teaching at Harvard, which concentrated on public law subjects like administrative law and public utilities as well as federal jurisdiction, see Roscoe Pound, Felix Frankfurter at Harvard, in 1 Felix Frankfurter: A Tribute 137, 140-43 (Wallace Mendelson ed., 1964). On Frankfurter's "old boy network," through which he placed his best students in the right clerkships and prepared them for careers in elite academic or government positions, see G. Edward White, Felix Frankfurter, The Old Boy Network, and the New Deal: The Placement of Elite Lawyers in Public Service in the 1930s, in INTERVENTION AND DETACHMENT: EsSAYS IN Legal History AND JurisprudenCE 149 (1994). Some have argued that Frankfurter was a minor administrative law scholar whose great achievement was in acting as a mentor to others. See ChAse, supra note 5, at 137-39; Thomas W. Merrill \& Kathryn Tongue Watts, Agency Rules with the Force of Law: The Original Convention, 116 HARV. L. REV. 467, 540-41 (2002). It seems a curious expression of academic priorities to call someone a minor scholar in the field when he trained a generation of scholars, lawyers, and officials in a particular approach that these former students retained and applied throughout their entire illustrious academic and public careers. Frankfurter himself considered his administrative law teaching to be among his most important tasks as an academic, and he purposely limited his administrative law seminars (as well as those on federal jurisdiction) to elite groups of Harvard's highest achieving students. Mary Brigid McManamon, Felix Frankfurter: The Architect of "Our Federalism," 27 GA. L. REv. 697, 751 n.329 (1993). Long into 
Frankfurter and his student (and later dean of Harvard) James Landis leading the way, the first-generation scholars of the late 1920 s and 1930s shared strong commitments to the idea that a powerful national administrative state led by experts was necessary to solve the most important political issues of the day. These experts would engage in a "systematic effort" to expand "the area of accredited knowledge as the basis of action" in the "intricate and technical facts" of a modern economy and society. ${ }^{45}$ "Regulation by government," according to John Dickinson, a former Frankfurter student, would promptly prevent future public harms caused by the inadequacies, failures, and collapse of the market by granting discretionary power to government agencies with "technical knowledge" unavailable to courts. ${ }^{46}$

Ultimately, the approach of first-generation administrative law scholarship emanated from three assumptions. First, federal administrative agencies, with their expertise, flexibility, and ability to consider systemic solutions to pressing national problems, were so necessary for a growing, modern nation that traditional constitutional understandings regarding the separation of governmental powers must yield - at least to some extent. ${ }^{47}$ Relying on the same Progressive Era traditions to which Freund and

their distinguished academic careers, Frankfurter's students continued to remember their mentor's administrative law seminars. See, e.g., Louis L. Jaffe, Administrative Law: Burden of Proof and Scope of Review, 79 HARv. L. REv. 914, 918-19 (1966) (describing the class period after the Supreme Court's decision in Crowell v. Benson, 285 U.S. 22 (1932), and using his memory of that event to describe Frankfurter's and Brandeis's conception of a flexible approach to administrative law). Moreover, claiming Frankfurter had secondary status as an administrative law scholar requires one to ignore the relevance of Frankfurter's extensive writings on federal jurisdiction and on the institutional role of the Supreme Court in the development of administrative law as a field. As I note in Part III below, he certainly did not consider that work irrelevant; to him, procedure and jurisdiction were crucial to legitimating administrative agencies and protecting the status of the judiciary. In his approach, a proper legal process was essential to a functional and legitimate administrative process.

45 Felix Frankfurter, The Public and Its Government 152 (1930).

46 John Dickinson, Administrative Justice and the Supremacy of Law in The UNited States 14-15 (1927). Dickinson dedicated the book "to Roscoe Pound and Felix Frankfurter, Pathfinders of the Law." Id. at v.

47 See WhITE, supra note 4, at 98-108. Separation of powers in this context refers both to the notion that the tripartite branches of government each have their own sphere of permissible activity that cannot be broached by another and to the notion that Congress cannot delegate its lawmaking powers to another enumerated branch of the government unless the unit of government delegated by Congress to exercise its power is itself an agent of the Legislature. 
Goodnow subscribed, legal academics sought to establish a legal environment that enabled government intervention to serve a range of economic and social reforms. ${ }^{48}$ Pound had proposed the development of a body of law that would challenge the existing "methods of broad generalization" of constitutionally permissible action. ${ }^{49}$ In Frankfurter's words, the administrative law considered by legal academics must offer "fluid tendencies and tentative traditions" and must protect against "sterile generalization unnourished by the realities of "law in action." "50 Thus, only an academic with a "rigorously scientific temper of mind" who is "able to move freely in the world of social and economic facts" would be capable of understanding and helping to construct a proper approach to administrative law. ${ }^{51}$ Caution about "government by experts" was not entirely misplaced, Frankfurter conceded, but external political controls and internal standards of performance developed by the expert professionals themselves could provide sufficient restraint. ${ }^{52}$ The law professor's role in the development of modern administrative law, then, was to nurture and promote the constitutional doctrine necessary to free experts to perform those tasks.

The first-generation administrative law scholars' second, and equally important, assumption was that notwithstanding the importance of administrative expertise, a limited judicial review should remain at the center of the process in order to declare congressional delegations of power to administrative agencies and agency actions themselves legal and legitimate. ${ }^{53}$ In the opening sentence of a chapter on "Legal Order in Fields of Disputed Social Policy" in his 1927 book Administrative Justice and the Supremacy of Law, John Dickinson described the essential but properly constrained role of the judiciary in this way: "Judicial review for so-called error of law is crucial not only as keeping open the necessary opportunity for the courts to compel observance of the law as previously formulated, but also as the channel through which they can carry forward the process of legal devel-

48 See Herbert Hovenkamp, The Mind and Heart of Progressive Legal Thought,

81 Iowa L. Rev. 149, 157-58 (1995).

49 Pound, Growth, supra note 43, at 336.

50 Felix Frankfurter, The Task of Administrative Law, 75 U. PA. L. REV. 614, 619 (1927).

51 Id. at 621.

52 Frankfurter, supra note 45 , at 157-60.

53 See Rabin, supra note 2, at 122-23. 
opment." ${ }^{54}$ For Dickinson, review of administrative action by a modern judiciary open to developing a common law of regulation would constitute "an instrument of the supremacy of law in building out new ground for the operation of general rules and principles." 55 Frankfurter agreed. ${ }^{56}$ Constitutional common law, correctly applied by right-minded judges, would give birth to a properly modern administrative law jurisprudence and, ultimately, to a properly modern administrative state. It was not the fault of the common law that some judges resisted the regulatory modernism preferred by an emerging generation of administrative law professors; rather, fault lay with those judges who improperly applied legal rules and concepts in new, inappropriate contexts. ${ }^{57}$ Indeed, agencies' successful regulatory practices and self-limiting operations, as well as judicial oversight, demonstrated that the law's supremacy was in no danger. ${ }^{58}$ Maintaining our traditional system of judicial justice, Frankfurter and Landis had argued, was of paramount importance, and administrative agencies must conform to that system. ${ }^{59}$

The third core assumption of early administrative law scholars was that legal academic research and teaching should focus on the traditional study of the judicial role in the administrative process - that is, on the limited judicial review of administrative agencies rather than on the bureaucratic operations and decision making of the agencies themselves. ${ }^{60}$ This approach assumed a binary relationship between the actual internal work of administrative agencies, which had been at least an element of Freund's and Goodnow's works, and the external law governing judicial

54 Dickinson, supra note 46, at 203.

55 Id. at 206; see Rabin, supra note 2, at 122-23.

56 See CHASE, supra note 5, at 14; Daniel R. Ernst, Willard Hurst and the Administrative State: From Williams to Wisconsin, 18 LAw \& Hist. Rev. 1, 13-14 (2000).

57 Dickinson, supra note 46, at 216, 334.

58 See I. L. Sharfman, The Interstate Commerce Commission: An Appraisal, 46 YALE L.J. 915, 948-50 (1937).

59 Felix Frankfurter \& James M. Landis, The Business of the Supreme Court: A Study in the Federal Judicial System 173-74 (Johnson Reprint ed. 1972) (1928).

60 According to William Chase, over the course of the first two decades of the twentieth century, Dean Pound had sought to avoid the issue of agency decision making, conceiving of it ultimately as a necessary evil of the Progressive Era that would surely disappear as it became unnecessary. Frankfurter's later resistance to Freund's conception of administrative law in legal academia as the study and development of agency procedures was intended to protect the role of legal academics and jurists from encroaching upon the work and decisions of administrative agencies. See Chase, supra note 5, at 107-13. 
review of the agencies' jurisdiction and procedures, which, within the Frankfurter approach, constituted the field of administrative law. ${ }^{61}$ Answering the question, What is administrative law? in a 1937 law review article, Frankfurter's casebook coauthor J. F. Davison rejected the internal approach as an impossible effort to classify the necessarily intuitive, experimental actions of agencies. ${ }^{62}$ At that time, there appeared to be no logical universal system of public administration discernible by law faculties or, as Davison noted, even by Justice Holmes, who had approvingly declared two decades earlier that administrative agencies base their decisions on "an intuition of experience that outruns analysis." 63 The internal approach was therefore significantly less appropriate for teaching and research than the external approach, which focused on a typical area of legal academic expertise: the refinement of constitutional common law principles. ${ }^{64}$

These efforts to create a modern conception of administrative law assumed that courts and legal academics would avoid intervention into the regulatory process at least for the present until a new administrative court (akin to courts of equity) was developed-which itself would not occur until regulatory procedures and practices had been regularized. ${ }^{65}$ Meanwhile, law schools across the country began to adopt new courses in administrative law that studied appellate decisions from federal and state courts of general jurisdiction using the case method, while the field of "public administration" arose concurrently in political science and government departments to develop rational and apolitical expertise in matters of policy and bureaucracy. ${ }^{66}$ Legal

61 See id. at 60-67 (citing WYMAN, supra note 43).

62 See J. F. Davison, Administration and Judicial Self-Limitation, 4 GEo. WASH. L. REv. 291, 296-99 (1936).

63 Id. at 298 (quoting Chicago Burlington \& Quincy Ry. Co. v. Babcock, 204 U.S. $585,598(1907))$.

${ }^{64}$ See Field, supra note 31; Louis L. Jaffe, The Contributions of Mr. Justice Brandeis to Administrative Law, 18 Iowa L. Rev. 213 (1933).

${ }^{65}$ CHASE, supra note 5, at 114-15. Scholars held fast to this assumption despite efforts by Congress and the bar to establish an administrative court that would develop an expertise in this area, intensively review the decisions of regulatory agencies, and even take over the agencies' power to adjudicate controversies surrounding their work. See Maxwell S. Isenbergh, Developments in Administrative Law, 19301940, 27 VA. L. Rev. 29 (1940); Louis L. Jaffe, Invective and Investigation in Admin. istrative Law, 52 HARV. L. Rev. 1201, 1221 (1939). Leading legal academics resisted and ultimately defeated such efforts in favor of mere procedural review of administrative decisions. CHASE, supra note 5, at 145-46.

66 CHASE, supra note 5, at 117-24. 
academia's limited focus on judicial review at once protected the expertise of lawyers, law professors, and the judiciary within the familiar methods of teaching and scholarship established in the late nineteenth and early twentieth centuries, and it also expressed the elite legal academy's Progressive Era commitment to expertise by presuming that administrative agencies should be protected from substantive judicial review. ${ }^{67}$ As one critic of this approach noted, the curriculum of administrative law classes before and (only to a slightly lesser degree) after World War II was concerned almost exclusively with appellate judicial opinions reviewing administrative decisions, and it gave little or no attention to the internal rulemaking or adjudicatory processes within agencies. $^{68}$

The first-generation scholars' exceptional concern with external judicial review rather than with internal agency operations also shaped the doctrinal issues on which they focused their attention. Frankfurter's coauthored 1932 casebook on administrative law spent more than half of its pages on constitutional challenges to legislation and administrative action, focusing especially on issues related to the separation of powers and congressional delegation of powers to agencies. ${ }^{69}$ This led one critic to characterize the casebook as "in effect a specialized work on constitutional law."70 Freund himself criticized what he saw as Frankfurter's excessive attention to constitutional issues, which contradicted Freund's focus in his earlier casebook on the common law and (to a lesser extent) statutory doctrines that affected agencies. Reviewing Frankfurter's casebook, Freund warned against encouraging law teachers and students to concentrate too heavily on the fleeting fashion of "juristic performance" in the field of constitutional law. ${ }^{71}$ Later authors abandoned the Frankfurter casebook's exceptional concern with constitutional issues but nevertheless continued to focus on the judicial review of constitutional issues as a major, preliminary consideration for a

67 See id. at 106-24, 134-35.

68 Esther L. Brown, Lawyers, Law Schools and the Public Service 179-82 (1948).

69 See Felix Frankfurter \& J. Forrester Davison, Cases and Other Materials on Administrative Law (1932).

70 Clark Byse, Book Note, Administrative Law-Cases and Comments, 25 IowA L. Rev. 839, 839 (1940).

71 Ernst Freund, Book Review, 46 HaRv. L. Rev. 167, 169-70 (1932) (reviewing Frankfurter \& Davison, supra note 69). 
course in administrative law. ${ }^{72}$

\section{James Landis and The Administrative Process}

As important as Pound's, Frankfurter's, and Dickinson's works were in the $1920 \mathrm{~s}$, James Landis, author of the seminal work The Administrative Process (1938) as well as Frankfurter's student and coauthor, was the most important theorist of administrative law in support of the New Deal. ${ }^{73}$ Originally delivered at Yale in the prestigious annual Storrs lectures in January 1938 and published as a book that same year, The Administrative Process was, at the time, the most coherent, accessible, and comprehensive account of the current state of administrative law from the perspective of a New Deal proponent. ${ }^{74}$ Well before his Storrs lectures-which he had originally been invited to deliver in 1935 but which were delayed while he served as chairman of the Securities and Exchange Commission-Landis had earned acclaim as a leading New Deal administrator, and he had recently become the dean of Harvard Law School. ${ }^{75}$

Landis explained that administrative agencies and the administrative legal process that shaped their work were a necessary outgrowth of the increasingly complex economy and society that modernity had engendered. As a result of both their historic necessity and their rational development, "the administrative process" of agency operations and administrative law had already achieved "great stature" and would only grow in the future. ${ }^{76}$ Landis considered the administrative process to be an optimal means of promoting government oversight because within its parameters, agencies could study an issue comprehensively in order

72 See, e.g., Walter Gellhorn, Administrattve Law: Cases and Comments (1940); see generally Byse, supra note 70, at 841, 846 (describing Gellhorn's casebook as "a significant and distinctive contribution" and as better serving an upper-division law school course in administrative law than its predecessors).

73 James M. Landis, The Administrative Process (1938). On Frankfurter's relationship with Landis, one of his favorite Harvard students, see Joseph P. Lash, $A$ Brahmin of Law: A Biographical Essay, in From the Diaries of Felix FrankFURTER 3, 35-36 (1975).

74 See Donald A. Ritchie, James M. Landis: Dean of the Regulators 84 $86(1980)$. It remains the standard text that casebook authors use to demonstrate the ideas of first-generation scholarship. See, e.g., Peter H. Schuck, Foundations of Administrative LAW 10-14 (2d ed. 2004) (excerpting Landis, supra note 73); Peter L. Strauss et al., Gellhorn and Byse's Administrative law Cases AND COMMENTs 27-29 (rev. 10th ed. 2003) (excerpting LANDIS, supra note 73).

75 See Ritchie, supra note 74 , at $62-82$.

76 See LANDIS, supra note 73 , at 5. 
to resolve a controversy as "rightly," rather than as fairly, as possible. ${ }^{77}$ Moreover, the regulatory state was necessary both to redistribute wealth to "ethical levels" and to maximize the total of society's wealth. ${ }^{78}$ To those who would complain of the administrative state's coercive nature in its efforts to maximize and distribute wealth, Landis asserted that in the state's absence, economic, legal, and political coercion would be performed by uncontrollable private entities rather than by a democratically elected and accountable government. ${ }^{79}$ Accordingly, Congress and the President should create more administrative agencies of greater expertise because only by doing so could government provide the "efficiency that is the desperate need." 80

In The Administrative Process, Landis dismissed as irrational those New Deal opponents who claimed that the Roosevelt administration's expansion in the number and size of federal agencies was unconstitutional. ${ }^{81}$ If a court faces a constitutional claim that legislation or an agency action violated separation of powers principles, it must recognize the constitutionality and necessity of both the delegation and the administrative act. Agencies that developed regulatory programs or adjudicated complaints after following proper procedures should prevail against constitutional challenges because the administrative process sufficiently balanced the constitutional branches of government and because the products of this process were far more important to the function of government and the preservation of political order than was

\footnotetext{
77 Id. at $38-40$.

78 Id. at 16.

79 See id. at 11 ("[T]he penalties that private management can impose possess a coercive force and effect that government even with its threat of incarceration cannot equal."); see also id. (noting that the management of a large corporation like U.S. Steel has power not only over its employees and customers but also "either by itself or in combination with its contemporaries can virtually determine what policies with reference to the production and sale of steel we shall pursue as a nation"). This argument echoes a central assertion of the legal realists that is most closely associated with Robert Hale, an economist by training and a professor at Columbia Law School from 1919-1949. See generally Barbara H. Fried, The Progressive As. sault on laissez Faire: Robert Hale and the First law and Economics MOVEMEnt 210 (1998); Neil Duxbury, Robert Hale and the Economy of Legal Force, 53 Mod. L. Rev. 421 (1990); Robert L. Hale, Force and the State: A Comparison of "Political" and "Economic" Compulsion, 35 Colum. L. Rev. 149 (1935); Robert Hale, Coercion and Distribution in a Supposedly Non-Coercive State, 38 POL. SCI. Q. 470 (1923).

80 LANDIS, supra note 73 , at 23-24.

81 See, e.g., id. at 4 (describing the critical "literature" regarding the administrative process as "abound[ing] with fulmination").
} 
the value of trying to preserve a static, outdated vision of "separate" powers. ${ }^{82}$ Thus, the relationship between agencies and Congress must be formally flexible but based on structural means of control. Successful statutory delegation would provide agencies with sufficient authority to devise and implement proper solutions to economic and social problems, and Congress would retain oversight through the appropriations process. ${ }^{83}$

Reviewing recent Supreme Court decisions on the constitutionality of the administrative state with a mixture of respect and criticism, Landis considered the extent to which the Court shared his vision of agency expertise and the judicial role of validating proper administrative processes and decision making. Landis praised the Court's decision in Humphrey's Executor, which upheld congressional constraints on the President's power to remove officers of independent agencies, ${ }^{84}$ because the decision demonstrated that the Court was coming to the mature realization that agencies needed and deserved sufficient "administrative freedom of movement" through discretion and independence. ${ }^{85}$ At the same time (and for the same reasons), Landis decried the Court's holding that agency findings of "jurisdictional" facts, the existence of which serve as "a condition precedent to the operation of the statutory scheme," 86 and constitutional facts, facts related to the alleged deprivation of a constitutional right, ${ }^{87}$ deserved no judicial deference. ${ }^{88}$ By creating and enforcing this distinction to protect its institutional prerogative, Landis argued

\footnotetext{
$82 \mathrm{Id}$. at 46.

83 See id. at 75-78.

84 Humphrey's Executor v. United States, 295 U.S. 602 (1935).

85 See LANDIs, supra note 73, at 115-16.

86 Crowell v. Benson, 285 U.S. 22, 54 (1932).

87 St. Joseph Stock Yards v. United States, 298 U.S. 38, 51-52 (1936).

88 See Ohio Valley Water Co. v. Ben Avon Borough, 253 U.S. 287, 289 (1920) (requiring judicial exercise of the Court's "independent judgment as to both law and facts" in review of administrative ratemaking record when the resulting rates are alleged to be constitutionally confiscatory); Ng Fung Ho v. White, 259 U.S. 276, 28385 (1922) (requiring independent judicial determination of the "essential jurisdictional fact" of citizenship in a habeas corpus challenge to deportation order); Crowell, 285 U.S. at 46 (holding that the judiciary must exercise an independent judgment regarding the constitutional jurisdiction of a federal agency); St. Joseph Stock Yards, 298 U.S. at 49 (holding that the judiciary has a duty "to exercise ... an independent judgment upon the facts" where a constitutional violation by a federal agency is alleged, although it may rely on a record developed by the agency). On the withering, but not death, of these doctrines in favor of an explicit deference to administrative decisions based upon substantial supporting evidence on the administrative record, see STRAUSS ET AL., supra note 74, at 973-78.
} 
(adopting the arguments in Justice Brandeis's dissents in St. Joseph Stock Yards v. United States and Crowell v. Benson) that the Court was inviting destructive judicial intrusion into the administrative process. ${ }^{89}$

In this regard, Landis shared legal realists' faith in expertise and their skepticism about abstract conceptions of constitutional law. Indeed, referencing and using legal realism's critique of formalism, he argued that courts must look not just at precedent and legal forms but at "other sciences" in order to understand the "incredible areas of fact" embedded in every systemic business problem. ${ }^{90}$ In facts and science lay the legal necessity and legitimacy for administrative agencies. The interdisciplinary and flexible expertise necessary to regulate economic behavior required more than a judiciary of narrow, irrelevant competencies whose expertise limited it to the important task of reviewing agency solutions for fairness and reasonableness. ${ }^{91}$

Despite his frustration with the Court's mixed record of respecting the administrative process and his realist antiformalism and faith in expertise, Landis nevertheless placed judicial review at the center of the administrative process. He adopted Justice Brandeis's declaration in his dissent in St. Joseph Stock Yards: "The supremacy of law demands that there shall be opportunity to have some court decide whether an erroneous rule of law was applied; and whether the proceeding in which facts were adjudi-

${ }^{89}$ See LANDIS, supra note 73, at 132-42 (discussing St. Joseph Stock Yards, 298 U.S. at 73 (Brandeis, J., concurring); Crowell, 285 U.S. at 65 (Brandeis, J., dissenting)).

90 See LANDIs, supra note 73 , at 31 . On Landis's and Frankfurter's relationships with realism, see infra notes 104-06 and accompanying text.

91 See LANDIS, supra note 73, at 30-31; see also id. at 32-34 (explaining additional advantages of regulation by administrative agencies to be their ability to engage in uniform, ongoing supervision of industries or disputes and their ability to create practical solutions based upon "all the available considerations" rather than generalized conclusions "drawn from the majestic authority of textbooks and cases" reached as a result of single disputes raised by individuals seeking to secure their rights). Indeed, he adopted an ironic realist tone when privileging agencies over the judiciary, dismissing the "lesser vision" that courts are inherently superior in all respects to administrative agencies because of courts' "delphic powers" and their "affinity with deep and mysterious principles of justice that none but [themselves] can grasp." Id. at 135; see also id. at 12 (describing critics' fetishization of the number three in their separation of powers arguments as "numerology"); id. at 47 (dismissing formalist fears that the administrative process unconstitutionally threatened the separation and independence of the tripartite government as "hysterical" and the result of "political conceptualization"). 
cated was conducted regularly."92 Courts offered specific areas of expertise as well as constitutional authority in adjudicating certain types of disputes between agencies and private parties. Judicial review could and indeed must play an important role in legitimating agency action that fell within agencies' broad authority as well as in checking unconstitutional congressional delegations to agencies and illegal agency behavior. He wrote, "[ $t]$ he line of demarcation [between facts and law, and agencies and courts] will then speak in terms of reality, in terms of an appreciation of the limitations and abilities of men, rather than in terms of political dogma and religious abstractions." 93 The administrative process ends, then, with judicial review of those issues about which courts have expertise: questions of law and procedure. Courts could retain their "supremacy" over issues requiring legal expertise, while agencies had unreviewable authority to consider those issues requiring factual expertise so long as they followed constitutionally and statutorily required procedures. This approach inevitably produced the proper application of expert knowledge. Judicial and administrative institutions, employing their relative competencies, could perform their necessary constitutional and statutory duties.

Operating in this manner, the law would continue to hold prestige and "grandeur" in a governing regime with powerful administrative agencies. Closing The Administrative Process, Landis waxed rhapsodic:

The power of judicial review under our traditions of government lies with the courts because of a deep belief that the heritage they hold makes them experts in the synthesis of design. ... The rise of the administrative process represented the hope that policies to shape ... fields [of social and economic regulation] could most adequately be developed by men bred to the facts. That hope is still dominant, but its possession bears no threat to our ideal of the "supremacy of law." Instead, it lifts it to new heights where the great judge, like a conductor of a many-tongued symphony, from what would otherwise be discord, makes known through the voice of many instruments the vision that has been given him of man's destiny upon this earth. ${ }^{94}$

The Administrative Process thus captures the confidence and

92 Id. at 124 (quoting St. Joseph Stock Yards, 298 U.S. at 84 (Brandeis, J., concurring)).

93 Id. at 153.

94 Id. at $154-55$. 
mood of first-generation scholars toward both administrative agencies and administrative law. Frankfurter, too, wrote confidently of this emerging consensus of administrative law, which he asserted constituted "the processes by which great activities of government . . . are subdued by the reason appropriate to them." 95 The "reason" advocated by Frankfurter and Landis was sufficiently systemic to encompass an enclosed universe of administrative and judicial processes with institutions that offered specific competencies and respected the boundaries within which they operated. But the "reason" was also sufficiently open to allow within those institutional boundaries the development of expert agencies capable of solving the problems faced by the modern state, as well as the cultivation of careful, wise, and prudent judges capable of resolving legal and constitutional issues only when necessary and within their courts' jurisdiction. In this regard, first-generation scholarship (and its increasingly widespread conception of administrative law) placed its Progressive embrace of an administrative state and its influences from legal realism alongside a parallel commitment to judicial review and a faith in the relative institutional capabilities of agencies and the judiciary. ${ }^{96}$

II

Arnold's Postrealist Approach to Administrative Law

Like his Harvard-affiliated contemporaries, Thurman Arnold

\footnotetext{
95 Felix Frankfurter, Introduction, 18 Iowa L. Rev. 129, 130 (1933).

96 My narrative is therefore considerably at odds with that of Keith Werhan, who describes pre-World War II administrative law as nearly a branch of legal realism. See Keith Werhan, The Neoclassical Revival in Administrative Law, 44 Admin. L. REV. 567, 574-76 (1992). Werhan's conception of administrative law is one of clear, delineated stages of development with great distinctions between the dominant theories of administrative law in each stage; mine, by contrast, sees continuity across the history of administrative law beginning in the New Deal era. In a better formulation, Mark Seidenfeld characterizes the shift between the New Deal's expertise model of administrative law and the postwar legal process model as less dramatic, insofar as he recognizes the place of judicial review even for New Deal advocates of the administrative state. See Mark Seidenfeld, A Syncopated Chevron: Emphasizing Reasoned Decisionmaking in Reviewing Agency Interpretations of Statutes, 73 TEX. L. Rev. 83, 91-93 (1994). My argument is that rather than a "shift," administrative law after World War II merely matured into and in relation to the legal process approach, that what Werhan calls the "realist" period was not especially realist, and that what Seidenfeld calls the "expertise" period was also deeply concerned with process.
} 
was wholly in sympathy with the leaders and proponents of the New Deal, whose efforts to bring about what he celebrated as the "great productive machine with new energy and efficiency"97 required the expansion of the federal administrative state. He explicitly advocated large-scale governmental interventions into the economy as a necessary response to the economic crisis of the Depression. He attributed the crisis to the "industrial feudalism" of private corporations that had caused widespread unemployment and then failed to respond to the plight of the legions of destitute people throughout the country. ${ }^{98}$ Thus, responding in 1936 to a query from The Nation magazine about what he expected of Roosevelt's second term, Arnold predicted success for an administration "which attempts, through organizations which it creates or controls, to step into areas where private enterprise is unable to operate effectively." 99 But that success would depend, Arnold warned, on the government developing practical, "efficient organizations"--not highfalutin' "new ideals" or a new "theory of government" about which the people could not care less. ${ }^{100}$ In order to facilitate the Roosevelt Administration's development of such organizations free from political and legal interference, Arnold focused his scholarly and more popular work on ways to limit and channel the judicial review of administrative agencies. In doing so, he engaged in the same general political and legal project as Frankfurter, Landis, and their cohorts in the first generation of administrative law scholars.

But Arnold's approach, which appeared in a law review article and his two mid-1930s books, was more radical. ${ }^{101}$ For one thing, his institutional and intellectual affiliations differed from theirs. He taught at Yale, having turned down a competing offer from Harvard (which he thought was filled with "colorless" young men $^{102}$ ) in favor of the "exciting" times he thought available to him with the realists in New Haven. ${ }^{103}$ Furthermore, Frank-

\footnotetext{
97 Arnold, Symbols, supra note 1, at 266-67.

98 Id. at $106-07$.

99 Thurman Arnold, What I Expect of Roosevelt, The NATion, Sept. 28, 1936, at 628.

100 Id

101 Arnold, Symbols, supra note 1; Thurman W. Arnold, The Folklore of CAPITAlism (1937) [hereinafter Folklore]; Arnold, Trial by Combat, supra note 13.

102 Letter from Thurman Arnold to Carl Arnold (May 20, 1932), in Voltaire AND THE COWBOY, supra note 7, at 186.

103 Letter from Thurman Arnold to Wilson Clough (Mar. 17, 1931), in Voltaire
} 
furter, Landis, and their Harvard-affiliated colleagues were not at the center of realism. ${ }^{104}$ The core of the Progressive/New Deal administrative law scholarship emerged from Harvard beginning in the early twentieth century in the scholarship of Bruce Wyman, Roscoe Pound, Thomas Reed Powell, Frankfurter, and the stream of Frankfurter's students like Dickinson and Landis who filled the ranks of law schools across the country. The core of the realist movement, by contrast, was located most prominently at Yale and Columbia. At the same time, some of the Harvardaffiliated administrative law scholars, like Dean Pound and J. Forrester Davison, Frankfurter's student and coauthor of his administrative law casebook, ranked among realism's fiercest critics (and in Pound's case, a fierce critic of the New Deal approach to administrative law, which his work had foreshadowed decades earlier, as well). ${ }^{105}$ Once ensconced at Yale as a close friend and associate of the core group of legal realists, Arnold became the rare realist-affiliated scholar who wrote extensively on administrative law. ${ }^{106}$

AND THE COWBOY, supra note 7, at 178. For an account of the realist milieu at Yale, see Kalman, supra note 11, passim; Robert W. Gordon, Professors and Policymakers: Yale Law School Faculty in the New Deal and After, in History of THE Yale Law School: The Tercentennial Lectures 75, 85-104 (Anthony T. Kronman ed., 2004).

104 Indeed, none of them appeared in Karl Llewelyn's famous list of realists. See Karl N. Llewellyn, Some Realism About Realism-Responding to Dean Pound, 44 HARV. L. REV. 1222, 1227 n.18 (1931) ("Frankfurter we do not include; he has been currently considered a 'sociological jurist,' not a 'realist.'"). But see HorwITz, supra note 5, at 213-25 (treating Landis and Frankfurter as realists).

105 See Neil Duxbury, Patterns of American Jurisprudence 153 (1995) [hereinafter Duxbury, Patterns]; Neil Duxbury, Faith in Reason: The Process Tradition in American Jurisprudence, 15 Cardozo L. Rev. 601, 618-21 (1993); $c f$. N.E.H. Hull, Roscoe Pound and Karl Llewellyn: Searching for an AmerICAN JURISPRUDENCE 212-15 (1997) (describing the debate between Pound and Llewellyn over the extent to which those on the periphery of the realist movement, which included Frankfurter and Landis, were sufficiently "realistic" and distinct from the legal academic norm). This is not to ignore the fact that many of the firstgeneration administrative law scholars saw themselves as antiformalist. Writing in 1927, for example, John Dickinson noted the "slumbering" common law tradition, Dickinson, supra note 46 , at 77 , that led government and law to be perceived as opposites and the latter to control the former "by the supposedly fixed and absolute standards of an Abstract Law," id. at 98-99. Landis also occasionally deployed a critical irony to his formalist predecessors that resembled realists' rhetoric. See supra notes 90-91 and accompanying text. But a limited antiformalism should not be confused with a fully committed realism, which core realists espoused.

106 See Duxbury, Patterns, supra note 105, at 154-55. Administrative law at Harvard was sufficiently different from a realist vision of administrative law to provoke Adolf Berle, a New Dealer at Columbia, to describe a "conflict between the 
More significantly, however, Arnold's approach to administrative law shunned the design of a properly limited approach to judicial review and the study of the judiciary's limited competence. Instead, it was primarily a critical theory of the symbolic practices of governance, which rejected a systematic, formal approach to administrative law. At the same time, Arnold tried to reconstruct a flexible, multifaceted administrative law from available and new legal doctrines with the hope of promoting a more efficient and effective state apparatus for overcoming the crisis of the Depression. In the sections that follow, I provide a concise summary of Arnold's postrealist approach before turning to his work on administrative law, where I consider his critical and reconstructive efforts in turn.

\section{A. Arnold's Postrealism}

Arnold has frequently been miscast by historians and commentators as one of the legal realists that swept the legal academy during the 1930s. ${ }^{107}$ Instead, as I have argued elsewhere, Arnold both extended and broke from realism by considering the implications of realist insights on areas of public law that mainstream realism had previously neglected and by using new critical methodologies to develop a singular, idiosyncratic approach to law. ${ }^{108}$ While the traditional legal realist critique revealed the historically constructed and contingent nature of the legal forms that legal formalists essentialized, ${ }^{109}$ Arnold instead inquired into the deeper importance of the cultural "symbols" and "folklore" of

idea of administrative law developed at Harvard and the idea of self executed law as we try to think of it at Columbia." NAvigating THE Rapids 1928-1971: From the Papers of Adolf A. Berle 150 (Beatrice Bishop Berle \& Travis Beal Jacobs eds., 1973).

107 See Kalman, supra note 11, at 34-35; William Twining, Karl Llewellyn and the Realist Movement 67-69 (1973); Douglas Ayer, In Quest of Efficiency: The Ideological Journey of Thurman Arnold in the Interwar Period, 23 STAN. L. Rev. 1049 (1971); Neil Duxbury, Some Radicalism About Realism? Thurman Arnold and the Politics of Modern Jurisprudence, 10 Oxford J. LeGal STUD. 11, 12 (1990); John Henry Schlegel, American Legal Realism and Empirical Social Science: From the Yale Experience, 28 Buff. L. Rev. 459, 511-12, 569-70, 570 n.589, 585 (1979).

108 See Fenster, supra note 8, at 1059-72. Much of what follows in this Part is a summary of that article. A more detailed development of and support for this summary is available therein.

109 The literature of and on realism, in its complexity and variable manifestations, is vast. The realism with which Arnold is associated and which most interested him was at once critical of prevailing formalism and conceptualism and committed to reconstructing a more functional, empirically based approach to law. See id. at 1061-66. The most trenchant recent accounts of realism are DuXbury, Patterns, 
governance, especially into the disjunction between the ideological spirituality of form and what he called the "temporal" needs of society and the functional means to address them. ${ }^{110}$ Like the realists generally ${ }_{111}^{11}$ Arnold's work featured both a critical and a reformist mode. ${ }^{112}$ Although his critical impulse was more prevalent in his writings (a tendency that remains the basis for his reputation), as I note in Part II-C, his ideas for a flexible approach to judicial review of administrative agency action were especially innovative (if not especially detailed and never followed explicitly by courts or commentators).

In developing his critical approach, Arnold appropriatedoften without clear attribution-the insights of the emerging qualitative social sciences of the early twentieth century. These included liberal psychologists and sociologists performing ideology and propaganda studies (most prominently Harold Lasswell, ${ }^{113}$ Vilfredo Pareto, ${ }^{114}$ and Walter Lippmann ${ }^{115}$ ), anthropologists and folklorists (such as Bronislaw Malinowski ${ }^{116}$ and Franz Boas ${ }^{117}$ ) studying the folkloric and symbolic practices of "primitive societies," and institutional economists (such as Thorstein Veblen ${ }^{118}$ and Walton Hamilton, Arnold's colleague at Yale ${ }^{119}$ ) who focused on the social context of economic and so-

supra note 105, at 65-159; Kalman, supra note 11; John Henry SCHLegel, AmerIcan Legal Realism and Empirical Social Science (1995).

110 ARNOLD, FolKLoRE, supra note 101, at 19-20.

111 See Kalman, supra note 11, at 3; Gary Peller, The Metaphysics of American Law, 73 CAL. L. Rev. 1151, 1220-26 (1985).

112 See Fenster, supra note 8, at 1064-66.

113 See Harold D. Lasswell, Psychopathology and Politics 183-93 (1930); Harold D. Lasswell, The Theory of Political Propaganda, 21 Am. PoL. SCI. Rev. 627 (1927); Harold D. Lasswell, The Function of the Propagandist, 38 INT'L J. ETHICs 258 (1928).

114 Vilfredo Pareto, 1 The Mind and Society at v-vi (Andrew Bongiorno \&

Arthur Livingston, trans., Arthur Livingston ed., 1935).

115 Walter LippmanN, Public Opinion 358-65 (1922).

116 See Bronislaw Malinowski, Crime and Custom in Savage Society (1926).

117 See Franz Boas, The Mind of Primitive Man, 14 J. Am. Folklore 1, 2-3 (1901); Franz Boas, The History of Anthropology, 20 SCIENCE 513, 519 (1904).

118 Veblen's major works include: Thorstein Veblen, The TheORY of THE LeIsure Class: An Economic Study of Institutions (1899); Thorstein Veblen, The Vested Interests and the Common Man (1919); Thorstein Veblen, The Place of Science in Modern Civilisation and Other Essays (1919); and Thorstein Veblen, Why Is Economics Not an Evolutionary Science?, 12 Q. J. Ec. $373,388(1898)$.

119 Hamilton's major works include: Walton H. Hamilton, Industrial Policy and Institutionalism: Selected Essays (Joseph Dorfman ed., 1974); Walton 
cial behavior. ${ }^{120}$ Although his focus was rarely on developing specific political or economic proposals, Arnold inherited from institutionalist economics the vision of a structural, mechanistic solution to the endemic weaknesses and imbalances of capitalism through, most prominently, such devices as government intervention in setting prices and wages and in disciplining corporations. ${ }^{121}$ Claiming to perform the role of "diagnosing the present difficulties" by seeking to understand and explain the context and pathologies of the political debates of the mid- to late-1930s and, ultimately, to intervene on the side of the New Deal with the prevalent intellectual tools of his era, ${ }^{122}$ Arnold analyzed the conservative political, economic, and legal formalisms that prevented the emergence of a modern industrial America that he thought would be able to overcome the Depression. ${ }^{123}$ A diagnosis of what he called "the taboos and customs of the tribe" (the symptoms of the dominant political culture that structure political discourse and extend into all of a society's institutions) was a necessary prerequisite to developing a properly functional, practical solution to the Depression or to any other crisis or problem faced by modern society. ${ }^{124}$ Arnold, therefore, proposed a shift from realism's focus on the mere critique of law's surface forms, practices, or temporal inefficiencies to an inquiry into the deeper spiritual, symbolic forms and practices that shape law as a field of governance.

Arnold thus aligned himself with legal formalists and traditional economists (whose work realists also critiqued) by arguing that certain assumptions regarding legal doctrine, political structure, and a capitalist economy seemed essential to the governing institutions of the United States. But he also agreed with legal realists that many of those assumptions were outdated, inefficient, and unjust. Unlike conventional realists, Arnold had little faith that mere reform would cure governing institutions and the public of their irrational investments in the symbols of government and capitalism. Such symbols, he argued, form the terrain

H. Hamilton \& Helen R. Wright, A Way of Order for Bituminous Coal (1928); and Walton H. Hamilton, Institution, in 7 ENCYCLOPEDIA OF THE SOCIAL SCIENCES 84 (Edwin R. A. Seligman ed., 1932)).

120 See Fenster, supra note 8, at 1078-94.

121 See Theodore Rosenof, Economics in the Long Run: New Deal TheoRISTS AND THeir Legacies, 1931-1993, at 1-11, 65-67 (1997).

122 Arnold, FolkLore, supra note 101, at 205.

123 Id.

124 Id. 
on which the struggle for political and legal changes takes place. Realists sought to debunk symbols; Arnold sought to understand and use them to reshape the public's beliefs in "a science about law" rather than a science of law. ${ }^{125}$

Arnold's project, then, was to develop a critical method and voice that could best understand (as his popular monographs named them) the "symbols of government" and the "folklore of capitalism." 126 The result was a provocative, though underdeveloped, approach to the study of governance that he called "Political Dynamics" 127 as well as an ironic and critical voice that remains memorable for its ability to deflate the pretentious assumption that legal and political institutions should somehow uphold consistent, timeless, abstract principles. ${ }^{128}$ A reflexive proponent of an excessive functionalism, Arnold sought only those policies and institutions that he thought could best maximize the welfare of citizens. ${ }^{129}$ But he did so while also recognizing the roles that culture and signification play within institutions and in society and the popular need to believe in consistent, timeless, abstract symbols. It was this dual approach-a postrealism that combined realism's critical functionalism with social science's interest in studying the prevailing culture and ideology of his time-that Arnold brought to the study of administrative law. I introduce that approach in the sections that follow.

\section{B. Critiquing the "Symbols" of Administrative Governance}

The final three chapters of Arnold's first book, The Symbols of Government (1935), use the critique of formalism that Arnold had developed in the book's previous chapters to condemn and

125 Thurman W. Arnold, Book Review, 36 Colum. L. Rev. 687, 690 (1936) (emphasis in original).

126 ARNOLd, SYMBols, supra note 1; ARNOLd, Folklore, supra note 101.

127 Arnold defined Political Dynamics as "a science about society which treats its ideals, its literature, its principles of religion, law, economics, political systems, creeds, and mythologies as part of a single whole and not as separate subjects, each with its own independent universe of principles." ARNOLD, FOlKLORE, supra note 101 , at 349.

128 See Fenster, supra note 8, at 1095-1100 (connecting Arnold's ironic voice to those of H.L. Mencken and Thorstein Veblen).

129 See, e.g., ARNOLD, Folklore, supra note 101, at 177 (adopting a normative principle "that it is a good thing to produce and distribute as much goods as the inventive and organizing genius of man makes possible"); see also ARNOLD, SYMBOLS, supra note 1, at 266-67 (arguing that functional, temporal governance was the most important goal of government and the basis of a "new humanitarian economic creed" that he hoped would sweep the United States). 
mock the judicial, jurisprudential, and political resistance to the administrative agencies associated with the New Deal. ${ }^{130}$ In the grand hierarchy of governing institutions, Arnold lamented, the administrative tribunal and agency faced a long, largely uphill battle. He contrasted the work of the tribunal and agency to the work of courts in a criminal trial, a powerful, well-known spectacle that provides a certain degree of comfort and satisfaction for political subjects in its procedural format and seemingly impartial application of substantive law. The administrative tribunal and agency could never compete with this popular conception of the judge and legal proceedings as upholders of the "Law." In their operations, administrative agencies simply failed to provide the necessary symbolic assurance that the underlying philosophical disputes about the relationship between the State and the individual had been fairly considered and resolved. ${ }^{131}$ More than any constitutional doctrine or political resistance, this symbolic deficit not only left agencies vulnerable to political and legal challenges, but it also rendered them inferior in power and prestige to the judiciary, which would resolve any legal dispute concerning agencies.

Like Frankfurter and Landis, Arnold's overriding legal focus in Symbols and his second book, The Folklore of Capitalism (1937), was on the judicial review of administrative agencies. Arnold was convinced that agencies enjoyed relative advantages in investigating and attacking the largest economic and social problems of the day. He claimed, for example, that administrative agencies would enable the country to benefit from their "huge reservoir of technical skill, capable of running a great productive machine with energy and efficiency." ${ }^{32}$ He rejected the traditional schema that juxtaposed administrative agencies (the looming, demonic symbols of bureaucracy) against the privileged judiciary (the supposedly neutral institution with sacred powers to interpret the Constitution and scrutinize legislative and administrative actions). ${ }^{133}$ For conservative members of the bar and bench, a strict separation of the tripartite branches of govern-

130 See ArNold, Symbols, supra note 1, at 172-271.

131 See id. at 133.

132 Id. at $266-67$.

133 Id. at 205-06. See also SHAMIR, supra note 6, at 99-100 (placing Arnold in the context of other elite lawyers and legal academics who championed administrative agencies over the judiciary as state actors most likely to respond effectively to the Depression). 
ment enabled the supremacy of a fetishized, presumptively apolitical and objective judiciary over unconstrained, political administrative agencies. ${ }^{134}$ It was this assumption, Arnold believed, that enabled a formalist, conservative judiciary to thwart the New Deal's efforts to promote the production and distribution of the "comforts" necessary to relieve the Depression. ${ }^{135}$

The problem, Arnold argued, was symbolic and procedural. Formalism's legal distinction between courts and agencies, which he happily debunked in his more conventional realist mode, was in fact constituted by the prevailing symbolic duality between courts and agencies. The rule of law and its various institutions and practices, in other words, were the result of a powerful need for symbols of authority and stability. Law's symbolic authority presumes a powerful judiciary that is fair, impartial, necessarily protective of individual freedoms, and therefore opposed to and above the dangerous "bureaucracy" of administrative agencies. The judiciary resolves disputes that the bureaucracy creates, and, in so doing, it demonstrates its inherent superiority in the hierarchy of government and in its ability to govern.

Most important, courts profit from their position as institutions that merely apply legal authority in the form of neutral rules of procedure and external, substantive common and statutory law. Courts rely on externally derived, preexisting, arcane rules of procedure and justiciability that protect them from the intrusion of heated political arguments and provide them with sufficient discretion to avoid certain disputes at certain times. Accordingly, even when the results of their decisions are difficult and troubling, courts are never at fault so long as they follow preconstituted fair procedures and preconstituted substantive law. ${ }^{136}$

134 Arnold was specifically reacting to the Court's reinvigoration of the nondelegation doctrine in the mid-1930s. See, e.g., Carter v. Carter Coal Co., 298 U.S. 238 (1936) (invalidating the Bituminous Coal Conservation Act of 1935 as an unconstitutional delegation of legislative power to fix hours and wages to certain coal producers and miners); A.L.A. Schechter Poultry Corp. v. United States, 295 U.S. 495 (1935) (declaring National Industrial Recovery Act unconstitutional because its codes of fair competition lacked enforcement standards); Panama Refining Co. v. Ryan, 293 U.S. 388 (1935) (declaring section 9(c) of National Industrial Recovery Act unconstitutional for granting the President the authority to determine and enforce policies regarding production and transportation of petroleum). These cases marked what G. Edward White calls the "unexpected" and temporary shift by the Court back to a "traditional separation of powers theory" in the mid-1930s. WHITE, supra note 4, at 108.

135 See Arnold, Symbols, supra note 1, at 252-53.

136 See id. at 205. 
Law's "supremacy"-a presumption shared even among proponents of administrative agencies ${ }^{137}$-inoculated the judiciary, as an abstract institution, from systemic criticism as well as from criticism directed at individual justices and judges who obstructed the development of administrative agencies.

Bureaucracies symbolized the inverse. They establish their own substantive rules and procedures, "that particularly silly form of rule and precedent known as red tape," which they apply to their subjects, and they therefore appear less objective and legal. ${ }^{138}$ Unlike the judiciary, which appears to be a neutral, apolitical institution that is physically and politically removed from the disputes it settles, agencies, as part of the Executive Branch, seem directly connected to the political hurly-burly. ${ }^{139}$

The judiciary also thrived', Arnold argued, by limiting itself and its exercise of power, while agencies were required to engage in vast acts of regulatory intrusion in order to achieve their mandated goals. Although courts gain prestige by appearing to settle disputes while making the law "more and more certain," they only actually settle limited issues presented before them, thereby "ow[ing] their power to the fact that they never clarify total situations." 140 By refusing to consider the next question that is likely to be brought to them or the implications of their own decisions, courts reserve their decisional capital and "obtain a power to keep litigants guessing." 141 Agencies, by contrast, are typically required by statutory mandate to develop comprehensive regulatory schemes and enforce civil law; as a result, they cannot perform their duties in such an incremental and restrained manner. ${ }^{142}$ Thus, they appear unduly intrusive, unwieldy, and bureaucratic, especially when compared to the removed, refined domain of the judiciary.

The epitome of this symbolic universe was the "trial by combat" model of litigating challenges to administrative action. In litigation, Article III courts adjudicate challenges to entire statutory and regulatory regimes through the prism of a dispute between one or more individuals and the agency and/or federal government. Arnold saw this as a foolishly inefficient and inde-

\footnotetext{
137 See supra text accompanying notes 53-59, 92-95.

138 See ARNOLD, Symbols, supra note 1, at 205.

139 Id. at 205-06.

140 Id. at 173 .

141 Id. at 174 .

142 See id.
} 
terminate means for evaluating the legality and wisdom of an agency's actions. ${ }^{143}$ Courts decide only individual cases and controversies brought to them by the parties to the suit, even when such cases represent a small part of a particular regulatory scheme. Courts also require parties to follow arcane procedural rules; base their decisions solely on a developed record produced by the parties themselves; and choose, where necessary, from a limited menu of remedies. ${ }^{144}$ In short, cases and the ensuing combat "must just happen" and may require the expenditure of millions of dollars and extensive delays-an approach that "does not permit a coherent or planned scheme for judicial participation in government regulation." 145

The appellate decision, the ultimate result of the trial by combat, is singularly unhelpful for regulatory programs. The Supreme Court's "delphic pronouncements" in the period leading up to its declaring the National Recovery Act unconstitutional, for example, often dodged the crucial constitutional issues that the public debated, and even its decision in Schechter Poultry failed fully to resolve the fate of any of the similar or related acts pending before Congress. ${ }^{146}$ Nevertheless, the Court merely added to its own luster by refusing to resolve the constitutional issues that it was charged with considering:

Here is a government of symbols in its most rarefied essence. The Court had played its hand with great skill, and emerged triumphant as an institution. The Constitution was more revered and feared than ever before. But still no one quite knew just what had happened,--what was constitutional, or what was unconstitutional. ${ }^{147}$

Courts separate themselves from the regulatory process by remaining "aloof from investigation and regulation" and awaiting a challenge to a specific "action or threatened action which has damaged, or is about to damage, some particular person." 148 By asserting their authority to decide the constitutionality of regulatory rules developed by an agency's investigation, courts could either dodge a controversy or "take pot shots at specific regula-

143 See generally id. at $172-98$ (criticizing "trial by combat" model of judicial review).

144 See id. at 184.

145 Id. at 181.

${ }^{146} I d$. at 176-77 (citing A.L.A. Schecter Poultry Corp. v. United States, 295 U.S. 495 (1935)).

147 Id. at $177-78$.

148 Id. at $182-83$. 
tions without being forced to assume responsibility for the regulatory scheme as a whole."149 Agency adjudications faced no better fate. To review individual complaints against regulatory enforcement, agencies such as the National Recovery Administration and the Agricultural Adjustment Administration developed their own internal administrative processes that incorporated legal folklore only to face uncertain appellate judicial review. ${ }^{150}$

Even when agencies defeated a challenge to a regulation or an action, they lost the larger war. In victory, agencies assumed the symbolic role of the bureaucratic victor over an individual subject to its regulatory power in a battle whose outcome was determined by the judiciary's higher, neutral authority. ${ }^{151}$ Judicial supremacy and a concomitant administrative inferiority emanate from the formalist symbolic hierarchy that privileges the judiciary and law over agencies and policy. The judiciary gives its blessing to the agency's action, thereby conferring it temporary legitimacy; future, more lasting legitimacy, however, will require further blessings provided at the conclusion of additional timeconsuming, expensive trials by combat.

This symbolic structure of administrative law produced the peculiar pathologies of legal resistance to the New Deal. Formalism's enduring symbolic construction of courts and administrative agencies perpetuated two folkloric beliefs: that courts protect individual freedom while administrative agencies are demonic forces of inefficiency and collectivity, and that "[c]ourts represent a rule of law above men" while administrative tribunals "apply practical considerations to court decisions."152 The symbolic assumptions of the formalist approach to administrative law granted conservative courts-already predisposed to strike down new regulatory regimes and rules under the false assumption that they were thereby protecting freedom-too much discretion to reverse agency decisions and the legislative authorization of regulation. Agencies were therefore relegated to secondary status behind the judiciary, especially when their specific actions or general legal authority faced a legal challenge. As a form of dispute resolution and state power, litigation appeared to

149 Id. at 189.

150 See Arnold, Trial by Combat, supra note 13, at 937-38.

151 See ARNold, Symbols, supra note 1, at 187.

152 Arnold, Folklore, supra note 101, at 372. 
be an essential, natural element of nineteenth century laissezfaire ideology, which remained prevalent in the mid-twentieth century. As such, litigation provided little more than
[A] series of miracle plays to give [the individual dispute and its judicial resolution] a theatrical development. In the mem- ory of the present generation the moral lesson of the judicial miracle play has been that rugged individuals are not regu- lated. Instead, they fight for their rights. In this battle they expect government to let them alone. ${ }^{153}$

The emerging field of administrative law practice and the firstgeneration administrative law scholarship decidedly failed to recognize this symbolic base and conservative bias of governance and litigation. In fact, first-generation scholars, despite their good intentions, merely proposed to mire agencies further in the folklore of judicial supremacy and procedure. Arnold likened efforts to develop a new administrative process, whether by New Deal proponents or critics, to the "double-headed system of law and equity" that failed to assist dispute resolution and only led to confusion among courts, attorneys, and laypeople. ${ }^{154}$ Because the prevailing symbolic hierarchy required a clear separation of regulatory agencies and the judiciary, he speculated, such confusion was likely to persist as academics developed their "dialectic exploration and footnotes" that would explain the correctness of a new system. ${ }^{155}$ For Arnold, an administrative state built around judicial supremacy would not, in the long run, achieve the larger goal of establishing independent, effective administrative agencies. And so he set out for himself the task of proposing an alternative means to provide a legal basis and structure for agency operations.

\section{Arnold's Administrative Law}

Like Landis and Frankfurter, Arnold saw the work of the administrative lawyer and law professors as focused on the scope and practice of judicial review. He assumed the necessity and legitimacy of administrative agencies within the modern state, and he wasted little time considering the actual practices and decisions of a particular agency. Accordingly, when Arnold proposed a notion of administrative law that was distinct from those

153 ARnold, Symbols, supra note 1, at 187-88.

154 Arnold, Trial by Combat, supra note 13, at 940 .

155 Id at 942. 
of either skeptics or proponents of the administrative state, he did so by rethinking the parameters of judicial review and the relationship among the three branches of government. In that regard, he was not akin to Frank Goodnow or Ernst Freund, whose work focused either on internal agency operations or means to police or expand agency discretion. Moreover, Arnold's view departed from that of his predecessors or contemporaries only with respect to judicial review of agency rulemaking; when "lowly and oppressed" individuals sought redress for particularized grievances through an adjudicatory challenge of a regulation as it applied to them, Arnold conceded that the judiciary must uphold the fundamental ideal of the fair trial. As he characteristically explained: "In the celebration of legal and economic theories [when reviewing rulemaking] the Court should be equipped only with prayer books and collections of familiar quotations. In the protection of those seeking a fair trial it should be armed with a sword which it dared to use with courage."156 Regarding the narrow but important legal issues surrounding the judicial review of administrative rulemaking, however, Arnold offered a radically distinct program from that of his contemporaries.

Arnold's proposed method of judicial review of regulatory administrative actions did not specifically require courts to uphold all such actions, whether proposed by Roosevelt's New Deal or by some other administration or political movement. ${ }^{157} \mathrm{He}$ did, however, assert that a judge who recognizes "the evanescent nature of any form of social bookkeeping will hesitate to interfere

156 ARnOLd, SYMBols, supra note 1 , at 197 . One might wonder how a realist like Arnold could be so secure in the adjudication/rulemaking distinction. The distinction had been established in the early part of the twentieth century in the procedural due process context and had been formulated in part by no less of an antiformalist than Justice Holmes. See Bi-Metallic Inv. Co. v. State Bd. of Equalization, 239 U.S. 441, 445 (1915) (Holmes, J.) (taxpayer had no right to expect individualized hearing before legislative revaluing of property); Londoner v. City and County of Denver, 210 U.S. 373 (1908) (individual property owners had a right to an individual hearing to challenge individualized special tax assessment on their property). It remains in force today despite protestation by no less of a formalist than Justice Thomas, who has challenged its logic in the context of Takings Clause jurisprudence. See Parking Ass'n of Georgia v. City of Atlanta, 450 S.E.2d 200 (Ga. 1994), cert. denied, 515 U.S. 1116 (1995) (Thomas, J., dissenting); see generally Peter L. Strauss, Revisiting Overton Park: Political and Judicial Controls Over Administrative Actions Affecting the Community, 39 UCLA L. REv. 1251, 1256-57 (1992) (discussing current salience of adjudicative/legislative distinction).

157 See Arnold, Symbols, supra note 1, at 196 ("There is no formula for the exercise of such a power."). 
with any exercise of governmental power which is sincere in its purpose and honestly designed as an experiment in social welfare."158 In a clear echo of Justice Holmes, Arnold warned against a court "stand[ing] guard over any legal or economic theory," lest that theory lose favor among scholars and legitimacy among the public. ${ }^{159}$ Ultimately, Arnold favored judicial solutions that would grant agencies the opportunity to experiment, that would require courts to review an agency's actions almost entirely in light of the interests of society as a whole rather than o in terms of the plaintiff's interests, that would provide "speedy methods" of appeal to the U.S. Supreme Court, and that would involve the participation of the judiciary in federal regulatory regimes. ${ }^{160}$

In an effort to enable "an orderly, planned participation of courts in the growing area of governmental regulation," Arnold proposed a number of solutions to the problems caused by the prevailing conception of strictly separate powers policed by a powerful judiciary. ${ }^{161}$ I discuss these below. Common among each of the methods he suggests was the assumption that necessary experimentation in the work of agencies and in the relationship between agencies and courts had been unduly checked by the relative hierarchy that granted the judiciary significantly higher status as well as power over administrative agencies. Courts could approve or strike down entire regimes months or even years after the agency had approved them, and agencies worked in fear that any new rules that they proposed would be similarly challenged and struck down at some indeterminate later date by some as yet unidentified court under some as yet unknown legal theory. ${ }^{162}$ Also common to each of these methods was the assertion that the lines between branches of government should not simply be redrawn or reconceived as permeable boundaries. Rather, they should be obliterated, and the judiciary should lend its prestige to agencies by engaging in active but limited oversight in the regulatory process while using its power and expertise to protect individuals challenging unfair and oppressive agency decisions. As Arnold explained in a letter to Felix Frank-

$158 I d$.

159 Id.; $c f$. Lochner v. New York, 198 U.S. 45, 75 (1905) (Holmes, J., dissenting)

("But a constitution is not intended to embody a particular economic theory.").

160 See Arnold, Trial by Combat, supra note 13, at 944-45.

161 Id. at 937.

162 Arnold, Symbols, supra note 1, at 192-93. 
furter, he thought that "a judiciary which was permitted to face real problems" would employ "looser and more practical" approaches to the problem of federal regulation and would invoke a rhetorical "dialectic" that was "more poetical and symbolic" in upholding and assuming the responsibility for "planned administration." 163 Arnold's proposals ultimately sought to appropriate and display the symbols of governance while subverting the first generation's tendencies toward creating logical systems of judicial review.

These proposals remained undeveloped in Arnold's work and lack even the appearance of a system or program. Rather, they are an exercise in antiformalist guerilla intervention into a field quickly solidifying around a coherent, systematic structure of agency expertise and judicial review. Despite their failure to cohere within an internally consistent system, Arnold's proposals do sort into three types: those that sought greater judicial involvement in rulemaking, those that enabled quicker judicial consideration of challenges to regulatory programs that courts would consider in a relatively nonadversarial context, and those that proposed greater agency independence from judicial review.

\section{Faster Judicial Decisions}

Arnold sought means to speed up the time-consuming process of litigation, which slowed development and implementation of agency programs. To this end, he embraced the declaratory judgment as well as (more controversially) the advisory opinion as a remedy and a procedure that would enable courts to reach a final decision without the formality of a trial or the risk of remedies that might otherwise attach to constitutionally impermissible actions. ${ }^{164}$ In the context of administrative law, the authority to issue declaratory judgments and advisory opinions would give legislators, regulators, and regulated parties the opportunity to know whether a statute or set of regulations are constitutionally permissible, and whether private actors' contemplated courses of conduct would run afoul of statutory and regulatory limits. ${ }^{165}$

Leaving aside the advisory opinion, which Arnold correctly predicted was so beyond the dominant jurisprudential common

${ }^{163}$ Letter from Thurman Arnold to Felix Frankfurter (June 11, 1934), in Voltaire AND THE CowBoy, supra note 7, at 201-02.

164 Arnold, Symbols, supra note 1, at 185.

165 Id. at 186. 
sense that it would not be adopted at the federal level, ${ }^{166}$ Arnold wrote during the period of the early twentieth century when the declaratory judgment had emerged as a legitimate judicial remedy for federal causes of action. A decade earlier, even the Progressive voice of Justice Brandeis had not only pronounced in Willing $v$. Chicago Auditorium Association that the declaratory judgment was beyond the power granted statutorily to the federal judiciary, but he also concluded that the remedy exceeded the justiciability limits of Article III's "cases and controversies" limitation. ${ }^{167}$ Frankfurter agreed: declaratory judgments were unwise and beyond the constitutional pale. ${ }^{168}$ Nevertheless, support for the declaratory judgment was substantial-large enough for a student author in the Harvard Law Review in 1938, likely sympathetic to Frankfurter's position, to characterize with mockery "[t] he familiar cry for a more speedy adjudication of constitutional issues free from 'technical' barriers."169 Indeed, state legislatures had begun to adopt the declaratory judgment in the early twentieth century, ${ }^{170}$ and five years after Brandeis's decision in Willing, the Court held that a suit originally brought in state court under the state's declaratory judgment act could present a justiciable appeal to the Supreme Court "so long as the case retains the essentials of an adversary proceeding, involving a real, not a hypothetical controversy, which is finally determined

166 See Charles Alan Wright \& Mary Kay Kane, Law of Federal Courts 65 (6th ed. 2002) (describing the rejection of the advisory opinion within the federal system as "the oldest and most consistent thread in the federal law of justiciability"); see also Richard H. Fallon et al., Hart and Wechsler's The Federal Courts and the Federal System 78-79 (5th ed. 2003) (reproducing correspondence between President George Washington's cabinet and the Supreme Court in which the Court refused to respond to a series of twenty-nine questions seeking "extrajudicial[ ]" answers).

167 See Willing v. Chicago Auditorium Ass'n, 277 U.S. 274 (1928). One rising star of the legal academy and student of Felix Frankfurter, Louis Jaffe, applauded Justice Brandeis's skepticism about the declaratory judgment to review legislation and administrative action. See Jaffe, supra note 64, at 217-18.

168 See Edward A. Purcell, Jr., Brandeis and the Progressive Constitution: Erie, the Judicial Power, and the Politics of the Federal Courts in Twentieth-Century America, 127-28 (2000); Felix Frankfurter \& Henry M. Hart, Jr., The Business of the Supreme Court at October Term, 1932, 47 HARV. L. Rev. 245, 286 n.96 (1933).

169 Note, Declaratory Judgments in Constitutional Litigation, 51 Harv. L. Rev. 1267, 1267 (1938).

170 See Edwin M. Borchard, The Uniform Declaratory Judgments Act, 18 MiNN. L. Rev. 239 (1934); Edwin M. Borchard, Declaratory Judgments in Administrative Law, 11 N.Y.U. L. Q. 139 (1933). 
by the judgment below."171 At least in part as a result of the Court's changed perspective, Congress passed the Federal Declaratory Judgment Act of $1934,{ }^{172}$ which the Court unanimously upheld against a constitutional challenge in 1937. ${ }^{173}$ Soon thereafter, declaratory judgments became a central remedy within administrative law. The original Administrative Procedure Act, passed in 1946, expressly permitted any person "adversely affected or aggrieved" by agency action to seek "Judicial Review" thereof by "actions for declaratory judgments." 174 Meanwhile, courts, commentators, and the Attorney General's Committee on Administrative Procedure praised the declaratory judgment as a remedy capable of solving disputes over administrative action. ${ }^{175}$

But Arnold wanted more from the remedy, and in the mid1930s, he criticized its impending domestication. He was convinced that declaratory judgments, like advisory opinions, were unlikely to emerge as a new way of testing and reviewing regulations because they would throw the Court into a political maelstrom that it sought to avoid in order to protect its "aloof and strategic position, and thereby its priestly power." ${ }^{176}$ The narrow vision of declaratory judgments in state legislatures (and, by implication, in the Supreme Court's requirements of appeals from state courts) blunted the remedy's radical potential by merely re-

171 Nashville, Chattanooga \& St. Louis Ry. Co. v. Wallace, 288 U.S. 249,264 (1933). Justice Stone, who authored the decision, had filed a separate concurrence in Willing refusing to conclude that declaratory judgments are beyond the constitutional scope of Article III courts.

172 Ch. 512, 48 Stat. 955 (1934) (codified as amended at 28 U.S.C. $\$ \S 2201-02$ (2000)).

173 See Aetna Life Ins. Co. v. Haworth, 300 U.S. 227 (1937).

174 Ch. $324, \S 10,60$ Stat. 243 (1946) (codified as amended at 5 U.S.C. $\$ \S 701-02$ (2000)).

175 See Quinones v. Landron, 99 F.2d 618, 620 (1st Cir. 1938) (citing as "one of the benefits" of declaratory judgments "the opportunity afforded to settle disputes arising over the powers, duties and privileges of administrative officers"); Committee on Administrative Procedure, Administrative Procedure in Government Agencies, S. Doc. No. 77-8 (1st Sess. 1941); Note, Declaratory Judgments: 1941-1949, 62 HARV. L. REv. 787, 874 (1949) ("In the field of public law, the declaratory judgment offers both government and the individual a means for the determination of disputed powers and duties which avoids the risk of taking action which may later prove to be illegal."); see also id. at 878-83 (citing examples of courts issuing declaratory judgments in administrative law decisions).

176 Arnold, Symbols, supra note 1, at 186; see also Arnold, Trial by Combat, supra note 13, at 930 (noting that declaratory judgments are "comparatively rare, probably due to the unfamiliar language of the formidable literature which has clustered about this ... logical device"). 
producing the old case and controversy requirement in a new form. Arnold complained (in a tone filled with irony and distaste), "The very fact that it has surrounded itself with such an enormous body of learned literature, philosophy, and cases during the brief period of its acceptance ... indicates that the framers of [declaratory judgment acts] have been anxious not to depart from the traditions of the past." ${ }^{177}$ And indeed, the federal act limited declaratory judgments to "cases of actual controversy," 178 a limitation that the Court cited as essential to the Act's constitutionality because it established a remedy and procedure resulting from "an adjudication of present right upon established facts" rather than "an advisory opinion upon a hypothetical basis."179 Decrying the excessively technical requirements of the federal declaratory judgment as it was understood and promoted by his Yale colleague Edwin Borchard, Arnold ultimately envisioned the remedy as a post hoc advisory opinion in which constitutional challenges to statutes and regulations could be adjudicated quickly, and in which courts could not avoid "inconvenient cases" through excessive " 'judicial' thinking" that forced the presentation of cases in particular ways at a particular stage of development. ${ }^{180}$

He also advocated, but was equally ambivalent about the prospect for, the use of injunctions as a remedy for challenges to New Deal legislation. ${ }^{181}$ Injunctions promised speedy resolution of issues at a preliminary stage as well as the possibility of ongoing jurisdiction and judicial oversight in administering the remedy. On the one hand, a request for injunctive relief allowed courts a certain degree of discretion in awarding and crafting a remedy while they still worked within the conventional framework of the trial by combat. But judicial use of the injunction was significantly less than perfect precisely because the legal standard for its issuance was too indeterminate. Within the trial by combat framework, courts could use the undefined irreparable harm standard to delay or strike down regulatory programs permanently, and a temporary injunction's cost and uncertainty might

177 Arnold, Trial by Combat, supra note 13, at 926.

178 Federal Declaratory Judgment Act, Ch. 512, § 1, 48 Stat. 955 (1934) (codified as amended at 28 U.S.C. $\$ \S 2201-02(2000))$.

179 Aetna Life Ins. Co. v. Haworth, 300 U.S. 227, 242 (1937).

${ }^{180}$ Letter from Thurman Arnold to Felix Frankfurter (June 11, 1934), in VoltaIRE AND THE Cowboy, supra note 7, at 202-03.

181 See Arnold, Trial by Combat, supra note 13, at 929-30. 
result in a de facto permanent end to an agency's efforts. ${ }^{182}$ Moreover, the requirement that a plaintiff seeking to enjoin enforcement of a statute or regulation must first violate it created an undue hazard for potential plaintiffs who feared having to face penalties if they failed to win. ${ }^{183}$ To Arnold, the litigation by case or controversy model, even when applied in the early and relatively speedy context of a preliminary injunction hearing, required unnecessary acts and considerations in order to obtain a resolution of the constitutional issue with which the interested parties were concerned.

\section{Greater Judicial Involvement}

Accordingly, Arnold considered options that abandoned the traditional litigation model. His proposals included not only excluding judicial review entirely, which I discuss in the next section, but, paradoxically, efforts to increase judicial involvement by including courts in the rulemaking process itself. The notion that courts and agencies should operate together as agency partners rather than as separate, often adversarial, elements within a system of government was not entirely new. ${ }^{184}$ Nor was the notion of partnership or collaboration foreign to administrative law scholars and advocates of the administrative state, including Justice Frankfurter himself. ${ }^{185}$

\footnotetext{
182 Id.

183 Id. at 930 .

184 Congress has a long history of creating specialized courts to ease the caseload burden faced by federal courts of jurisdiction, developing judges with specific expertise in complex areas and long-term oversight of agency operations, and increasing the efficiency of adjudicating disputes. See Harold H. Bruff, Specialized Courts in Administrative Law, 43 AdmIN. L. Rev. 329, 330-31 (1991). Though still formally separate, such courts promised to solve some of the problems Arnold and others identified with traditional federal judicial review. In Arnold's time, the most recent effort to create a specialized court to review decisions by one agency was the Commerce Court that President Taft proposed in 1910 to review Interstate Commerce Court decisions. See FrankfurTer \& Landis, supra note 59, at 153-74. Taft envisioned the court as a means to bring together disparate economic and political interests, to support the development of the administrative agency and its professional expertise, and to overcome the institutional obstacles to administrative regulation generally. See SKOWRONEK, supra note 10, at 262-63. For largely political reasons resulting from the perception that it favored railroad interests, the court failed miserably and lasted only three years. See George E. Dix, The Death of the Commerce Court: A Study in Institutional Weakness, 8 Am. J. Legal Hist. 238 (1964). For an overview of specialized courts today, see FALLON ET AL.; supra note 166, at 41-46.

185 See United States v. Morgan, 313 U.S. 409, 422 (1941) (describing agencies and courts as "collaborative instrumentalities of justice"); see generally Warren W. Gardner, Federal Courts and Agencies: An Audit of the Partnership Books, 75 Colum. L.
} 
But Arnold's efforts, predictably, were intended to push courts more emphatically and structurally into partnerships with agencies. The most radical of these efforts would have courts treat agencies' regulatory schemes "as they $\mathrm{d}[\mathrm{o}$ ] [the courts'] own masters, referees, or receivers . . . [u]nder a scheme of discretionary review." 186 Courts could thereby "approve or disapprove administrative regulations as they were formulated" and would therefore be responsible for "definite rules." 187 As a result, a judiciary engaged in Arnold's conception of administrative law would serve as "an investigating body" rather than as "an arbiter of combats." 188 Such supervisory review would prevent the judiciary from invalidating agencies' necessary experimentation with new rules and administration. Courts would presumably be privy to the information and insights of experts without the cumbersome procedures of civil litigation and would also experience the difficulties and frustrations of formulating a regulatory response to a complex set of economic and social issues. The distinction between administrative and judicial processes would thereby collapse, or at least the processes would progress simultaneously. Agencies would operate as junior partners to courts in a partnership whose purpose was to develop regulatory programs. As a result, agencies would no longer perceive courts as adversarial authorities whose review begins only after the agency has fully developed its own programs. ${ }^{189}$

Arnold saw existing judicial processes as analogous to this proposal and as potentially useful as well. Although it would soon be codified in Rule 53 of the Federal Rules of Civil Procedure, judicial use of a special master was a longstanding tradition in courts of equity, ${ }^{190}$ and the new rule largely adopted existing doc-

REv. 800, 800-03 (1975) (tracing judicial and commentators' use of "partnership" metaphor).

186 ARnold, Symbols, supra note 1, at 191.

187 Id. at 191-92. Arnold conceded, however, that nondeferential judicial review of specific administrative actions should apply in instances in which an agency or commission makes quasi-judicial decisions. In those instances, agency actions are more likely to appear arbitrary and personal, and a court's review of the agency's action is more likely to be based upon and limited by the kinds of issues (such as due process) over which courts have expertise. See id. at 202-03.

188 Id. at 192.

$189 \mathrm{Id}$. at $191-92$.

190 James R. Bryant, The Office of Master in Chancery: Colonial Development, 40 A.B.A. J. 595, 595 (1954). 
trine and practice. ${ }^{191}$ Arnold saw the court-appointed master and receiver models offered as an apparatus by which courts could, at their discretion, appoint and adopt an objective adjunct to supervise, investigate, and come up with proposed resolutions to a particular matter. ${ }^{192}$ For similar reasons, Arnold identified the corporate reorganization, in which federal courts relied upon receivers, committees, and masters to oversee judicial and corporate administration, as another model for agency-court partnerships. ${ }^{193}$ In the optimal equity receivership process that emerged by common law innovation, federal district courts oversaw a process by which the debtor and all of his or her creditors and bondholders would negotiate a plan to enable the bankrupt corporation to get back on its feet financially. ${ }^{194}$ At the time Arnold drew this analogy in the mid-1930s, his friend and Yale colleague William Douglas was helping to lead efforts to reform federal bankruptcy law in part by rationalizing receivership procedures through new federal statutes and, ultimately, by increasing federal oversight of the bankruptcy process through Securities and Exchange Commission investigations of large corporate reorganizations. ${ }^{195}$ For Arnold, the openness, collaboration, and relatively active judicial involvement of the reorganization processes seemed to offer flexibility that was lacking in classic adversarial litigation. ${ }^{196}$

Arnold also wanted to develop a means by which courts could retain ongoing jurisdiction over regulatory programs. He applauded the Supreme Court's decision in Appalachian Coals, Inc. $v$. United States, for example, where the Court affirmed a panel

\footnotetext{
191 Armistead M. Dobie, The Federal Rules of Civil Procedure, 25 VA. L. Rev. 261, 291 (1939).

192 For a thorough description of the duties to which courts assigned masters during the first half of the twentieth century (covering the period both before and after codification), see Irving R. Kaufman, Masters in the Federal Courts: Rule 53, 58 Colum. L. Rev. 452, 462-69 (1958). On the continuing tension in American trial practice over the use of special masters to enable courts to gather and understand scientific evidence, see Margaret G. Farrell, Coping with Scientific Evidence: The Use of Special Masters, 43 EMORY L.J. 927 (1994).

193 Arnold, Trial by Combat, supra note 13, at 930-31.

194 See David A. Skeel, Jr., Debt's Dominion: A History of Bankruptcy LAW IN AMERICA 56-60 (2001).

195 See id. at 101-09; see also Cloyd Laporte, Changes in Corporate Reorganization Procedure Proposed by the Chandler and Lea Bills, 51 HARV. L. REv. 672, 67577 (1938).

196 See Arnold, Trial by Combat, supra note 13, at 930-31. Arnold criticized limitations placed on the court's record that prevented a judge from supervising a bankrupt corporation's transactions after approval of the reorganization plan. See id.
} 
of district court judges who had held "a suit open for purpose of experimental development" to see if an otherwise per se illegal combination of coal producers could nevertheless act in a reasonable manner to save the coal industry in Appalachia. ${ }^{197} \mathrm{Al}-$ though it reversed the lower court's ruling that a combination of coal operators had violated federal antitrust laws, the Court remanded the case with instructions that the lower court could retain jurisdiction for the purpose of taking remedial measures in the event that the defendants' future operations proved to be illegal and against the public interest. ${ }^{198}$ This was precisely the kind of flexible innovation and oversight by courts that allowed continuing jurisdiction over efforts to address significant economic issues that Arnold sought to encourage.

\section{Minimize Judicial Involvement}

Arnold also sought means to enable agencies to bypass, or at least minimize, judicial oversight. When courts could not or would not engage in productive oversight, minimizing or avoiding judicial review altogether would protect the significant work of agencies. To that end, he favored the consent decree, which he would later use extensively as head of the antitrust division of the U.S. Justice Department from 1938 to $1943 .{ }^{199}$ Since the mid1920s, the Justice Department had increasingly resolved civil suits enforcing antitrust laws against anticompetitive business activities through consent decrees in which defendants agreed to prospective injunctions against future illegal activity. ${ }^{200}$ This was an equitable means to end enforcement actions through tailored injunctions negotiated by the government and defendants. The government's authority to enter into and hold parties to the

197 Id. at 928 (citing United States v. Appalachian Coals, Inc., 1 F. Supp. 339 (W.D. Va. 1932), rev'd, 288 U.S. 344 (1933)).

198 Appalachian Coals, 288 U.S. at 378, overruled in part on other grounds, Copperweld Corp. v. Independence Tube Corp., 467 U.S. 752 (1984).

199 See Alan Brinkley, The End of Reform: New Deal Liberalism in ReCession and War 111-12 (1995); Ellis W. Hawley, The New Deal and the Problem of Monopoly 429-30 (1966); Milton Katz, Consent Decrees and Antitrust Administration, 53 HaRv. L. Rev. 415 (1940); Spencer Weber Waller, The Antitrust Legacy of Thurman Arnold, 78 ST. JoHN's L. REv. 569 (2004).

200 See William J. Donovan \& Breck P. McAllister, Consent Decrees in the Enforcement of Federal Anti-Trust Laws, 46 HARV. L. REv. 885, 885-86 (1933). The attorney general used consent decrees significantly more often in the antitrust context because of provisions in the Sherman and Clayton Acts granting federal courts the authority to provide prospective injunctive relief against future criminal anticompetitive activity. See Katz, supra note 199, at 416-19. 
terms of their consent decrees had been upheld by the Supreme Court in two decisions in the years immediately preceding Arnold's work on administrative law. ${ }^{201}$ In Swift II, its second consent decree decision, the Court also limited the ability of lower courts to modify existing decrees to "[n]othing less than a clear showing of grievous wrong evoked by new and unforeseen conditions." ${ }^{202}$ To Arnold, the consent decree offered federal agencies welcome discretion in regulatory and legal enforcement with limited judicial oversight in crafting penalties and resolutions and without cumbersome, fixed rules of judicial review. ${ }^{203}$ In the words of commentators writing contemporaneously with Arnold, the consent decree represented "law enforcement by negotiation" and enabled the parties to use alternative means to "settle[ ] economic questions of great public importance" without the direct intervention of potentially conservative courts and the trial by combat mode of judicial dispute resolution. ${ }^{204}$

In a proposal that would have avoided judicial review altogether, Arnold suggested that agencies use arbitration with regulated parties to "escape . . . the judicial hunt for issues" by settling disputes over the constitutionality of legislation and agency action. ${ }^{205}$ Of course, advocating arbitration to settle disputes over matters of law-especially matters of constitutional law-merely begs the questions of whether and to what extent a party to arbitration could seek judicial review of the resulting decision or agreement. Arnold did not offer an answer, but in his typical fashion, he mocked the unquestioned presumption that a nonjudicial resolution of a dispute was inherently less fair and authoritative than a judicial one simply because of the institutional authority of the decision maker. ${ }^{206}$ For Arnold, the increasingly widespread use of arbitration as an "escape from law" made plain the unsettling fact that the "judicial system has been

201 See Swift \& Co. v. United States (Swift I), 276 U.S. 311 (1928); United States v. Swift \& Co. (Swift II), 286 U.S. 106 (1932).

202 Swift II, 286 U.S. at 119 , overruled by Rufo v. Inmates of Suffolk County Jail, 502 U.S. 367, 380 (1992) (holding that the current Fed. R. Civ. P. 60(b)(5) set down a "less stringent ... standard" intended to meet the "need for flexibility in administering consent decrees").

203 Arnold, Trial by Combat, supra note 13, at 928. Interestingly, Arnold did not propose either the consent decree or an Appalachian Coal-type judicial oversight in Symbols when he adapted (and shortened) the earlier Trial by Combat article.

204 Donovan \& McAllister, supra note 200, at 912.

205 ARNold, Symbols, supra note 1, at 187.

206 Arnold, Trial by Combat, supra note 13, at 928-29. 
unable to include the settlement of many important types of disputes." 207 Dispute resolution, in other words, was more important to Arnold than the resolution of broad legal issues that appellate courts purportedly offered. But arbitration was imperfect, Arnold conceded, not least because arbitration agreements to settle disputes had "become technical and full of pitfalls" and thereby defeated the purpose of avoiding the symbolic jurisprudential constraints that had originally led him to seek refuge in arbitration as an alternative model. ${ }^{208}$ Nevertheless, arbitration at least offered a model for moving parties toward a reasonably agreeable resolution outside the folkloric realm of the trial by combat and its initial uncertainty, its absolute winners and losers, and its presumption of judicial superiority.

\section{Conclusion}

Reform was inevitable, Arnold speculated, although it would not be immediate; he believed that an imminent groundswell of popular belief in planning and a concomitant abandonment of laissez-faire as an economic ideal would surely drive courts to "intelligent procedural planning." 209 Such reform was not likely to sweep away the old symbols, ${ }^{210}$ but the "practical elasticity" and relative indeterminacy of those symbols would allow for the emergence of a new, more efficient relationship between courts and agencies, while the traditional symbols of judicial review would survive to meet the "pontifical needs" and "deeply felt emotional want" of lawyers and the general public. ${ }^{211}$ The emergent New Deal and the residual formalist folklore, in other words, would by necessity coexist.

Although he recognized the importance of an independent judiciary as a symbol of governance, Arnold happily and creatively considered any functional solution that would enable agencies to work what he believed to be their instrumental magic. He eschewed both a case-driven focus on the federal appellate adjudication of constitutional issues by common law development and

207 Id. at 929.

208 ArNold, Symbols, supra note 1, at 187.

209 Arnold, Trial by Combat, supra note 13, at 945.

$210 \mathrm{Id}$. at 947 . Nevertheless, at the end of both his 1934 article and Symbols, Arnold did hold out the possibility that the attachment to "trial by combat" was disappearing despite his earlier commitment to the notion that such symbols had deep roots in popular and professional thought. See id. at 947.

211 Id. at 946-47; see also ARNOLD, SYMBOLs, supra note 1, at 268-71. 
the creation of a newfangled approach to administrative law based on a comprehensive federal statute and a federal administrative court. Instead, consistent with his general approach to legal thinking and pedagogy, he embraced an oddly inventive method of creating new means to avoid the trial by combat in pragmatic ways. In the preface to his casebook on trials, judgments, and appeals that he coauthored with his Yale colleague Fleming James, Arnold declared:

[F]rom the point of view of this book, legal principles are regarded as an argumentative technique-in other words, as an arsenal of offensive and defensive weapons to be used in litigation. . . Inventiveness and ingenuity in the use of legal analogies are actually far more important in legal battles than scholarly learning. ${ }^{212}$

And so it was with his vision of the "principles" of administrative law. Arnold's conception of administrative law and government regulation declared the need for structural change in a manner that, through the strategic deployment of existing symbols and laws, would not appear to be as radical as it was. Ultimately, his tenure as head of the Antitrust Division was in part an effort to implement this change. ${ }^{213}$ In his willingness to see through and abandon entirely the contingent, constructed symbols of judicial supremacy as well as the constitutional monolith requiring the separation of government's tripartite branches, and in his eagerness to attack them offensively and defensively with both shopworn and newly formed weapons, Arnold stood alone.

III

The "Mumbo-Jumbo of Legal Jargon":

Frankfurter, Arnold, and the Procedural

Core of Administrative Law

Arnold's lonely, outlying stance and kit bag approach to administrative law opposed the emerging consensus building around notions of relative institutional competencies and of judicial review as a limited but important safeguard for the modern liberal democracy. As a prominent legal academic, Arnold and his proposals did not go unnoticed. In correspondence with Arnold and in the public forum of his casebook on federal jurisdic-

212 Thurman W. ARnold \& Fleming James, JR., Cases and Materials on Trials, Judgments and Appeals, at v-vi (1936).

213 See Rosenof, supra note 121, at 10. 
tion, Felix Frankfurter summarily rejected Arnold's vision of a more active judiciary engaged alongside administrative agencies in the regulatory state. In so doing, Frankfurter and his coauthors clarified a vision of a judicial process that should be separate from, that should follow on, and that ultimately should structure and trump the administrative process in which he and Landis had so much faith.

This Part uses Frankfurter's comments on Arnold and Frankfurter's original works to identify the differences between the vision of administrative law developed by first-generation scholars and Arnold's criticism and alternative approach. This contrast foregrounds the procedural core of administrative law by revealing what Frankfurter and Arnold saw as the stakes of the first generation's project. For Arnold, the logical system of administrative law stood in the way of the administrative state; for Frankfurter, administrative law provided the procedural protection that would enable both an administrative state and a stable, powerful judiciary.

Arnold was friends with both Frankfurter and Landis from at least his early days at Yale. ${ }^{214}$ The elder Frankfurter read his work and on occasion sent him comments. After reading Trial by Combat and the New Deal (in which Arnold first developed his approach to administrative law), Frankfurter praised its "frolicsome learning" and "liveliness of spirits."215 Frankfurter was deeply skeptical of Arnold's interest in developing creative, flexible roles for the judiciary in the administrative process. He ultimately rejected Arnold's approach and satirized what he described as Arnold's refusal to distinguish " 'right' or 'wrong.'" 216 He sarcastically characterized Arnold's proposals as a call for a "new deal by the judiciary, with its slogan 'government of the people, for the people and by the courts." "217 Arnold's proposed "juristic offensive," Frankfurter suggested, appeared to be a secret plot to "arouse popular revulsion and thus lead to the appropriate confinement of judicial power." 218

214 See Letter from Thurman W. Arnold to Carl Arnold (May 20, 1932), in Voltaire AND the Cowboy, supra note 7, at 186.

215 Letter from Felix Frankfurter to Thurman Arnold (undated) (on file at the University of Wyoming).

216 Id.

$217 \mathrm{Id}$

$218 I d$. They maintained this cordial rivalry throughout the 1930s. A few years later, after Arnold's success with Symbols and Folklore, Frankfurter sent Arnold a 
Whether Arnold secretly hoped courts would actively oversee administrative regulation so that their failure would destroy judicial authority and status-which is the implication of Frankfurter's criticism-is unclear. Perhaps, as Frankfurter suggested, Arnold was covertly trying to achieve what he had argued two years earlier in a major article in the Harvard Law Review: that procedure can serve as "an escape from substantive law" when the relevant legal rules seem opposed to reaching a desired result. $^{219}$ At minimum, Frankfurter clearly considered Arnold's ideas a bizarre effort to extend administrative law beyond constitutional limits.

In a 1928 monograph that he wrote with Landis, Frankfurter had begun to articulate a Progressive theory of the judiciary, imagining it as an institution with coherent and well-defined authority operating in a modern nation-state in which jurisdiction and procedure were themselves instruments of ends or "means of effectuating policy."220 And later, in an article written with Henry Hart, he advocated judicial resistance to the "undue suction into the avoidable polemic of politics" that arose from considering any and all constitutional challenges to the administrative process. ${ }^{221}$ In that article, which was published the same year as Arnold's Trial by Combat, Frankfurter and Hart thoroughly embraced the "seemingly technical rules" of jurisdiction as both a form of "wise statecraft" and as a set of "procedural safeguards" intended to protect the judiciary from "subtle or daring attempts at procedural blockade-running."222 Federal courts generally, and the Supreme Court specifically, must be

clipping from an editorial in the Montgomery (Ala.) Advertiser linking recent work by the two New Deal academics. His cover note asked, "Isn't it funny for them to link me with you? Haven't they heard of Newton and Einstein and Karl Marx and J.C.?" It is unclear which role Frankfurter saw himself playing in those pairings. Letter from Felix Frankfurter to Thurman Arnold (Jan. 24, 1938) (on file at the University of Wyoming).

219 Thurman Arnold, The Role of Substantive Law and Procedure in the Legal Process, 45 HARv. L. Rev. 617, 642-47 (1932) [hereinafter Role]; see generally Charles M. Yablon, Justifying the Judge's Hunch: An Essay on Discretion, 41 Has. TINGs L.J. 231, 244-46 (1990) (contextualizing Arnold's argument within his advocacy in favor of the administrative state).

220 Frankfurter \& LANDis, supra note 59, at 2; see also Edward A. Purcell, Jr., Reconsidering the Frankfurterian Paradigm: Reflections on Histories of Lower Federal Courts, 24 Law \& Soc. INQ. 679, 683-84 (1999).

${ }^{221}$ Felix Frankfurter \& Henry M. Hart, Jr., The Business of the Supreme Court at October Term, 1934, 49 HARv. L. Rev. 68, 90 (1935).

222 Id. at 91. 
strict regarding jurisdiction in constitutional cases to use the "accumulated experience" that has formed "the tradition of constitutional adjudication." 223 Proceeding in what Frankfurter and Hart declared was the traditional manner allowed the justices to appear as "statesmen," and, most important, enabled "continuance of the Court's traditional share in the government of our democratic society." 224 If it proceeded otherwise, the Court would affirmatively create or assert itself in interbranch disputes in a way that could threaten its hard-won prestige. ${ }^{225}$ In his 1938 review of the Court's decision to find jurisdiction to review congressional actions in cases challenging the constitutionality of the Tennessee Valley Authority ${ }^{226}$ and the Bituminous Coal Conservation Act, ${ }^{227}$ Frankfurter found instances in which-regardless of whether one agreed with the Court's ultimate decision to uphold or strike down these two representative New Deal legislative schemes-the Court's very grant of jurisdiction demonstrated that it had foolishly fallen prey to the "imponderable pressure of the public importance of the statutes under review."228 If the doctrine of constitutional review that cautioned against bowing to such pressure were further unsettled, Frankfurter cautioned, "unnecessary friction [would be added] to the complicated workings of our government; it weakens the responsibility of Congress in shaping policy; it undermines vital confidence in the disinterested continuity of the judicial process." 229

In his casebook on federal jurisdiction (written with Harry Shulman), Frankfurter pitted his and Hart's argument about the necessity of federal jurisdiction's role as a bulwark preventing the judiciary's involvement in substantive matters against Arnold's efforts to use procedure to force courts to resolve substantive disputes as quickly and thoroughly as possible. ${ }^{230}$

223 Id. at $93-94$.

224 Id. at 94.

225 Id. at 94,98 .

226 See Ashwander v. Tennessee Valley Auth. (TVA), 297 U.S. 288 (1936) (upholding the constitutionality of the TVA's authority to compete with private power companies in the sale and distribution of electric power to consumers).

227 See Carter v. Carter Coal Co., 298 U.S. 238 (1936) (striking down as unconstitutional the wage and hour commissions of the Bituminous Coal Conservation Act).

228 Felix Frankfurter \& Adrian S. Fisher, The Business of the Supreme Court at the October Terms, 1935 and 1936, 51 HARv. L. REv. 577, 627-28 (1938).

229 Id. at 637.

230 See Felix Frankfurter \& Harry Shulman, Cases and Other Authorities on Federal JuRisdiction ANd Procedure 92-94 (rev. ed. 1937) (excerpting 
Consecutive excerpts within the casebook's opening chapter covering the constitutional limits on federal jurisdiction and procedure reveal the crux of these opposing views. For Frankfurter and Hart, jurisdictional limitations, most notably the case or controversy requirement, reflected the "accumulated experience of a century and a half" of constitutional adjudication. ${ }^{231}$ Arnold, by contrast, saw no need for a case or controversy requirement at all and considered it mere priestly ideology that limited dispute resolution to small, narrow issues argued by exaggeration and partisanship. ${ }^{232}$ A rigid case or controversy requirement was hardly a forward-thinking doctrine to encourage development of administrative operations necessary to the modern state. "The common law," Arnold argued, "is neither clear, sound, nor even capable of being restated in areas where the results of cases are being most bitterly contested. And particularly with reference to administrative regulation does mutual exaggeration of opposing claims negative the whole theory of rational, scientific investigation."233 To Frankfurter, this was foolish and silly:

It is neither intellectual timidity nor adherence to the mumbojumbo of legal jargon that has made the Supreme Court from the very outset, on appeals to it, give very restricted scope to the concept of "case" or "controversy." The instinct of statesmen who were either participants in or witnesses to the fashioning of the Constitution decisively rejected any practice which would make of the Court a standing body of expert expounders of the Constitution. If the Court was to have the vital function which it evolved for itself, the occasions for its authoritative intervention had to be severely circumscribed. ${ }^{234}$

When courts respect and utilize the restraint and discretion offered by jurisdictional limitations, Frankfurter, his coauthor Hart, and his coeditor Shulman claimed, they engage in a reasoned effort to preserve the institutional competence of the judiciary.

Frankfurter and his collaborators offered the most sophisticated vision of judicial restraint of all the first-generation administrative law scholars. They assumed that proper, constitutionally limited legal process both sufficiently constrained the administra-

Frankfurter \& Hart, supra note 221, at 90-98); id. at 94-95 (excerpting Arnold, Trial by Combat, supra note 13, at 919-22).

$231 \mathrm{Id}$. at 92 (quoting Frankfurter \& Hart, supra note 221, at 90).

232 See id. at 94-95 (excerpting Arnold, Trial by Combat, supra note 13, at 919 . 22).

$233 \mathrm{Id}$. at 95.

234 Frankfurter \& Hart, supra note 221, at 94. 
tive process and allowed that process to develop expert policy. For Arnold, a judiciary restrained by a limited vision of its constitutional duty and authority unduly delayed the implementation of necessary federal regulation, provided courts with political cover from difficult decisions, and delegitimated agencies relative to courts by simultaneously claiming authority to pass constitutional judgment over agency action and refusing to do so in a particular instance (while reserving the privilege to do so later). For first-generation administrative law scholars, the judicial process was an entity apart from and superior to the administrative process; for Arnold, judicial and administrative processes were secondary to, and themselves merely part of, the regulatory project of New Deal governance. One advocated a timeless, presumptively nonideological constitutional system without any necessary substantive end; the other championed a contingent, historically necessary, appropriate regulatory project that sought to respond to an economic and political crisis.

A series of friendly exchanges between Frankfurter and Arnold in early 1936 that began in response to the Supreme Court's decision in United States v. Butler ${ }^{235}$ crystallized their opposing views. ${ }^{236}$ The Court in Butler held that the processing tax at the core of the Agriculture Adjustment Act of $1933^{237}$ was an unconstitutional invasion of the reserved powers of the states and exceeded Congress's taxing and spending authority under the general welfare clause. ${ }^{238}$ In his majority opinion, Justice Roberts declared that the "only" duty of the judicial branch when faced with an "appropriately challenged" act of Congress is "to lay the article of the Constitution which is invoked beside the statute which is challenged and to decide whether the latter squares with the former." ${ }^{239}$ For Justice Stone, joined by Justices Brandeis and Cardozo in dissent, the majority's willingness to strike down a key portion of the Act in its entirety in response to a suit by the receiver of an agriculture commodity processing company that owed taxes from previous years ignored an essential "guiding principle" of constitutional adjudication: the judiciary should show necessary and prudent self-restraint in the face

235297 U.S. 1 (1936).

236 Letter from Thurman Arnold to Felix Frankfurter (Jan. 8, 1936) (on file at the University of Wyoming).

237 Ch. 25 , 48 Stat. 31.

238 Butler, 297 U.S. at 74-75.

239 Id. at 62. 
of efforts to seek constitutional invalidation of seemingly "unwise laws" and should properly defer the power of repeal to "the ballot" and "the processes of democratic government."240 Similarly, Walter Gellhorn, in his 1940 casebook, would later characterize Justice Roberts's statement and approach to adjudication as one "made by the learned justice more for the delectation of the newspaper-reading public than for the enlightenment of the profession" and as akin to support for the issuance of advisory opinions. ${ }^{241}$

As a supporter of the New Deal, Arnold was opposed to the substance of the Court's decision. ${ }^{242}$ But the majority's willingness to consider the constitutionality of the entire statute was consistent with his desire for speedy and dramatic adjudication. Tongue firmly in cheek, Arnold wrote Frankfurter two days after the decision was issued, saying that he "never dreamed" he would have such influence on the Court and that he knew of no source other than his article "where the Court could find authority for making such a broad decision." 243 Frankfurter agreed, returning Arnold's letter with a handwritten note characterizing him as a "prophet." 244 Three months later, after the Court issued its Carter Coal decision invalidating the Bituminous Coal Conservation Act of 1935 as an unconstitutional delegation of legislative power to fix hours and wages to certain coal producers and miners ${ }^{245}$ Frankfurter sent Arnold a mocking telegram in which he complained that the decision

[C]onvinces me that my devotion to ancient Supreme Court doctrine that the ... Court should confine itself to the case in the record is completely outmoded and should be abandoned by sound men everywhere. Stop. You were right. Stop. I was wrong. Stop. And so [I] apply herewith for membership in your seminar where these inevitable judicial tendencies to spread opinions all over the map are explained with the aid of your almost uncanny penetration into judicial psychology.

240 Id. at 78-79 (Stone, J., dissenting).

241 GellHoRn, supra note 72, at 133.

242 See Thurman W. Arnold, Debate-Affirmative: Prof. Thurman W. Arnold, in New York State Bar Ass'n, Proceedings of the Fifty-Ninth Annual Meet. ING 159, 162-63 (1936) (arguing against the majority decision in Butler and in support of that part of Justice Stone's dissent asserting the constitutionality of the A.A.A.).

243 Letter from Thurman Arnold to Felix Frankfurter, supra note 236.

244 Felix Frankfurter, undated annotations to Letter from Thurman Arnold to Felix Frankfurter, supra note 236.

245 Carter v. Carter Coal Co., 298 U.S. 238 (1936). 
Stop. I am now a convert to your statesmenlike doctrine of contracting jurisprudence by enlarging it which is probably the best substitute that can be adopted for sociological jurisprudence in these curious times. ${ }^{246}$

Arnold apparently (and somewhat sarcastically, at least in this exchange) hoped that the Court's occasional striking down of New Deal legislation might establish a new, dramatic jurisprudential approach, that-no matter the substantive result-would be incidentally beneficial to legislators and agencies by accelerating the validation (as well as invalidation) of regulatory programs. Frankfurter was appalled at the potential danger to the Court's institutional prestige this approach would create, even if the Court's invalidation of key parts of the New Deal might lead to a political and popular upheaval in support of New Deal programs and against the conservative Court. At minimum, Arnold embraced the long-term regulatory gains that would result from removing the uncertainty of piecemeal litigation, and he may even have enjoyed seeing, as Frankfurter suspected, the prospect of an administration that he favored facing a wounded Court. His vision was, in the end, a strategic litigator's vision of administrative law that sought to use existing procedure to achieve a particular substantive result. While Frankfurter supported the same substantive aspects of the New Deal, his attachment to a philosophical, normative, and systemic vision of legal process outweighed his politics.

\section{IV}

\section{The Administrative Process and the Legal Process Approach}

The legal process Frankfurter and the first generation of administrative law scholars triumphed as a corollary to the administrative process foreshadowed the post-World War II emergence of what became known as the "legal process" approach. ${ }^{247}$ When they framed the proposed field of administrative law doctrine, research, and teaching as a matter of institutional design within a seamless system of law and governance, first-generation scholars had laid the groundwork for the intellectual ferment that fol-

\footnotetext{
246 Letter from Felix Frankfurter to Thurman W. Arnold (May 22, 1936) (on file at the University of Wyoming).

247 Again, my narrative is at odds with that of Keith Werhan, who argues that the legal process approach was imported into administrative law after World War II. See Werhan, supra note 96 , at 577-78.
} 
lowed. ${ }^{248}$ Frankfurter's student and coauthor, Henry Hart, would become one of the leading proponents of the legal process approach as would many of Frankfurter's other Harvard students and his Supreme Court clerks. ${ }^{249}$ Legal process came to dominate legal education in the postwar period; today, it remains a pervasive, if not quite predominant, characterization of governance and especially of the judiciary's role within it. ${ }^{250}$ As it further developed in the ideas of first-generation administrative law scholars, the legal process approach came to shape the entirety of American postwar public law scholarship, providing both a legitimating set of procedural norms and practices for the growing administrative state and a flexible approach to the varied and changing purposes for which federal agencies would be used. ${ }^{251}$ This Part draws connections between the scholarship of prewar administrative law theory and the postwar legal process approach and argues that by both criticizing the emergence of a formal, systematic vision of administrative law and proposing a quite different set of relationships between courts and agencies, Arnold forecasted the triumph of a process-centered approach and saw that approach's functional, conceptual, and political limits in advance.

\section{A. The Institutional Core of the Legal Process Approach}

Because first-generation administrative law scholars had focused on designing a system of judicial review that would enable

248 See William N. Eskridge, Jr. \& Philip P. Frickey, Historical and Critical Introduction to Henry M. Hart, Jr. \& Albert M. Sacks, The Legal Process, at li, lxi-lxii (William N. Eskridge, Jr. \& Philip P. Frickey eds., 1994). Let me be clear as to the limits of this relationship. I am decidedly not arguing that the first-generation administrative law scholarship of Frankfurter and Landis directly created the legal process approach, which focused largely on issues relating more directly to federal courts and jurisdiction. Landis and especially Frankfurter were concerned with more practical and political matters than the postwar legal process scholars, whose work tended towards a much higher level of abstraction. Rather, the earlier work was an important influence with somewhat different political motivations that operated within a distinct historical context. See Purcell, supra note 168, at ch. 9; Purcell, supra note 220 , at 705 n. 76 .

249 See Laura Kalman, The Strange Career of Legal Liberalism 29, 25859 n.35 (1996).

250 See William N. Eskridge, Jr. \& Philip P. Frickey, The Making of the Legal Process, 107 Harv. L. Rev. 2031, 2032-33 (1994).

251 See William N. Eskridge, Jr. \& Gary Peller, The New Public Law Movement: Moderation as a Postmodern Cultural Form, 89 MicH. L. Rev. 707, 709-10 (1991); Mark Tushnet \& Timothy Lynch, The Project of the Harvard Forewords: A Social and Intellectual Inquiry, 11 Const. COMMENT. 463, 475 (1994-95). 
the emergence of an optimal administrative process, they did not anticipate the entirety of the legal process paradigm. ${ }^{252}$ Briefly identifying the elements of the legal process approach, however, makes plain the historical connection between the two. The legal process approach commanded that judges should rely on "reasoned elaboration" expressed in fulsome, consistent, and rational decisions, ${ }^{253}$ engage in a "maturing of collective thought" through the careful, incremental exercise of common law development, ${ }^{254}$ and, ultimately, create and protect a self-limiting judicial institution that performs those tasks in which it is competent. ${ }^{255}$

This latter assertion about institutional competence demonstrates the essential continuity between first-generation administrative law scholarship and contemporary administrative law theory. It rests on a presumption about the structural determination of governance and states a commitment, both as a matter of theory and normative consequence, to a permanent allocation of decision-making within specific and appropriate institutions. ${ }^{256}$ In an article on criminal law, Henry Hart declared that institutional competence is "axiomatic," insisting that "each agency of decision ought to make those decisions which its position in the institutional structure best fits it to make."257 Settled institutional structures are "more fundamental than the substantive arrangements in the structure of a society," Hart wrote with his coauthor Albert Sacks, because they distribute decision making among institutions from the private ordering of the market to the interconnected institutions of government, thereby serving as "the source of the substantive arrangements and the indispensable means of making them work more effectively." 258 The primary purpose of law's core "constitutive or procedural understandings or arrangements" is to respect and protect insti-

252 For a useful summary of the range of embedded assumptions in the legal process approach, see Richard H. Fallon, Jr., Reflections on the Hart and Wechsler Paradigm, 47 VAND. L. ReV. 953, 964-66 (1994).

253 HART \& SACKs, supra note 248 , at 145-50.

${ }^{254}$ Henry M. Hart Jr., The Supreme Court, 1958 Term-Foreword: The Time Chart of the Justices, 73 Harv. L. Rev. 84, 100 (1959).

255 See HART \& SACKs, supra note 248, at 696, 1009-11.

${ }^{256}$ Eskridge \& Frickey, Historical and Critical Introduction, supra note 248, at xciv-xcvi.

${ }^{257}$ Henry M. Hart, Jr., The Aims of the Criminal Law, 23 Law \& Contemp. Probs. 401, 426 (1958).

${ }^{258}$ HART \& SACKS, supra note 248 , at 3-4. 
tutional structures, which legal process adherents considered more fundamental than mere substantive arrangements. ${ }^{259}$ Only properly delimited institutional structures enable "well-informed and wise decisions" and optimal results. ${ }^{260}$

The legal process approach's institutional core and concern with structure echoes similar tendencies in first-generation administrative law theory. To make this connection even clearer, consider the relatively brief treatment that Henry Hart and Albert Sacks gave in their famous casebook materials ${ }^{261}$ to the place of administrative agencies within the legal process. ${ }^{262}$ They presumed a settled system in which, despite the "great variety" of administrative powers, "the dynamics of subsequent growth" in the "arrangement" of administrative regulation "follow a distinctive pattern."263 Official responsibility for formulating policy, elaborating statutory authority, and developing methods of individual adjudication lies first in the administrative agency to which regulatory authority was generally delegated, regardless of whether the legislation bestowed these specific powers on the agency or was silent. ${ }^{264}$ Its "first-line status" grants the agency the opportunity, without judicial assistance, to establish regulatory programs and adjudicatory arrangements on which regulated parties can rely, and this spares courts from the burden of handling "the great mass of controversies" itself. ${ }^{265}$ "On appropriate challenge" to agency action or the underlying legislation itself, courts function as a "second-line" reviewing agency with the duty to determine the constitutionality of the statute and regulatory program and whether the agency action was authorized by the statute. ${ }^{266}$ Viewed from the perspective of first-generation administrative law scholars, legal process theory's commitment to institutions and structures would appear quite familiar. Look-

\footnotetext{
$259 \mathrm{Id}$. at 3.

$260 \mathrm{Id}$. at 154.

261 The casebook materials, though never completed and officially published (they were widely adopted as mimeographed drafts), provided the name, the agenda, and much of the analytical structure for the legal process approach. See Eskridge \& Frickey, Historical and Critical Introduction, supra note 248, at liii.

262 The materials treated administrative law and process only briefly on the assumption that students would consider the subject more thoroughly in an administrative law course. See Hart \& SAcKs, supra note 248, at 1060-61.

$263 \mathrm{Id}$. at 165.

264 Id. at 165-66.

$265 \mathrm{Id}$. at 1291.

266 Id. at 166-67.
} 
ing backward at the historical and thematic connections between the two, we can see more clearly the procedural core of early modern administrative law, with its pretensions of structural protection against judicial overreach for the agencies, alongside the more permanent and important judicial institutions adjudicating issues within their own core competencies. ${ }^{267}$

\section{B. Against Theology: Arnold, Henry Hart, and Judicial Process}

In 1960, at the legal process approach's apogee, Thurman Arnold published a scathing attack on Henry Hart in the Harvard Law Review responding to Hart's criticism of what Hart deemed unreasoned and unprofessional opinions issued by certain members of the Warren Court. ${ }^{268}$ Using a fairly simple empirical method, Hart had complained that the Court was deciding too many cases too quickly, ${ }^{269}$ and as a result, it was issuing decisions that lacked "the underpinning of principle which is necessary to illumine large areas of the law and thus to discharge the function which has to be discharged by the highest judicial tribunal of a nation dedicated to exemplifying the rule of law." 270 To prove his point, Hart provided a detailed exegesis of the Court's recent grant of habeas corpus in Irvin v. Dodd, ${ }^{271}$ a decision in which Hart felt the Court provided a "transparently indefensible reading [of the Indiana Supreme Court opinion denying the capital defendant's appeal of his conviction due to a biased jury and improper prosecutorial conduct] in order to strike down jurisdictional barriers to the consideration of federal claims." 272 In this decision, and in others generally, the Court had failed to follow the proper legal process that would "illumine large areas of the law" and establish "impersonal and durable principles of consti-

267 I concede that my focus in drawing the connection between legal process theory and administrative law is limited to issues of institutional competence and the function of judicial review. Missing from this account is legal process theory's conception of legislative interpretation, which Keith Werhan emphasizes. See Werhan, supra note 96 , at 579-80. My different emphasis results from my different historical narrative of the relationship between legal realism, first-generation administrative law scholarship, and legal process theory. See supra notes 96, 247.

268 See Thurman Arnold, Professor Hart's Theology, 73 Harv. L. Rev. 1298 (1960) [hereinafter Theology] (responding to Hart, supra note 254).

269 See Hart, supra note 254, at 85-94.

270 Id. at 99.

271359 U.S. 394 (1959).

272 Hart, supra note 254, at 110. 
tutional law." 273 Hart closed his jeremiad by warning that reason, not merely a temporary majority of justices, is the life of law, and he concluded that such reason had been lost in the operations of the Warren Court. 274

Although Arnold had left Yale and academia in 1938 for the Justice Department and had then served briefly on the Court of Appeals for the District of Columbia before establishing the law firm that would become Arnold \& Porter ${ }^{275}$ he felt strongly enough about his old nemesis's criticism to defend in print a Court that included many of his own friends. ${ }^{276}$ After disagreeing with Hart's close reading of Irwin, ${ }^{277}$ Arnold dismissed his larger argument that the Court's purportedly incompetent decisions failed to uphold the institution's standard. In the same critical and ironic voice that he had wielded decades before, Arnold argued that principles were not immutable and that the operations of the Supreme Court, with its nine diverse members, often resulted in difficult decisions with fragile majorities-unlike the opinions of legal academics who, Arnold believed, used the limitless time available to them to propose platitudes and unworkable legal propositions in the Harvard Law Review ${ }^{278}$ Worse, Arnold alleged, was Hart's conception of the proper judicial process and the competent judicial institution, which had evolved into a new conservative formalism in which Hart and his cohorts criticized the Court on procedural and formal grounds in order to condemn the Court's increasingly liberal tendencies. ${ }^{279}$

Here, in a somewhat changed but still recognizable form, was the complaint Arnold had lodged against Hart and his colleagues

273 Id. at 99.

$274 \mathrm{Id}$. at 125

275 See Voltaire and THE Cowboy, supra note 7, at 51-94.

276 See id. at 88.

277 See Arnold, Theology, supra note 268, at 1304-10. In an article that was otherwise supportive of Hart and critical of Arnold, even Hart's dean, Erwin Griswold, found his analysis of Irvin lacking. See Erwin N. Griswold, Foreword: Of Time and Attitudes-Professor Hart and Judge Arnold, 74 HARv. L. REv. 81, 83 (1960).

278 See Arnold, Theology, supra note 268, at 1312-14.

279 See id. at 1314-17. The argument that legal process used procedural means to further conservative political commitments is fairly common. See, e.g., Gary Peller, Neutral Principles in the 1950's, 21 U. Mich. J.L. ReForm 561, 566-68 (1988); Michael Wells, Busting the Hart \& Wechsler Paradigm, 11 Const. Comment 557, 564-67 (1994-95). But see KalmaN, supra note 249, at 30-36; Eskridge \& Frickey, Historical and Critical Introduction, supra note 248, at cvi-cxiii, cxx-cxxi (defending legal process proponents against charges that they opposed the Warren Court's desegregation decisions and were latter-day formalists). 
more than twenty years earlier-even though he saw the Henry Hart of 1960 as an unsympathetic associate of the conservative corporate bar rather than as a fellow New Deal advocate. ${ }^{280}$ Hart's legal process approach, it seemed, had confirmed Arnold's original suspicion that underneath the apparent New Deal advocacy of first-generation administrative law scholars lurked the pernicious thought of conservative formalism dating back to the pre-New Deal era. Legal process had appropriated many of realism's tendencies and insights, including its focus on procedure and its recognition that the judiciary is an active agent of decision making - an agency whose decisions make law rather than find it. ${ }^{281}$ In doing so, however, it articulated realism's lessons in distinct ways by focusing on systemic rather than functional ends. The original legal process proponents studied-and legal process adherents continue to study-procedure to develop and protect the judiciary's institutional competence as appellate tribunals built upon reason rather than to create detailed, functional procedural regimes. ${ }^{282}$ Like realists, legal process adherents diverged from the scientific naturalism of classical legal formalism. Despite this commonality, however, legal process ultimately proposed a strict set of categorical distinctions between law and policy, between branches of government, and between principled reason and unprincipled, willful activism-distinctions that constitute the basis of what Morton Horwitz has called an "institutional formalism." 283

For Arnold in 1960 as in the mid-1930s, the fetish of process, institutions, and systems came at the expense of a frank consideration of substance. Systems would not aid political efforts to improve the economy and society any more than they had aided the New Deal, and the wider social benefits that would flow from these political movements, Arnold presumed, vastly outweighed any loss that would be incurred by an "unprincipled" Court or a nonsystematic administrative law. Law's role was to further sub-

\footnotetext{
280 Arnold, Theology, supra note 268 , at 1315 .

281 See Duxbury, Patrerns, supra note 105, at 211-12; G. Edward White, The Evolution of Reasoned Elaboration: Jurisprudential Criticism and Social Change, 59 VA. L. REv. 279, 284-86 (1973).

282 See White, supra note 281, at 286.

283 See Horwitz, supra note 5, at 254; see also Richard A. Posner, Overcom. ING LAw 75-77 (1995) (associating the legal process school with classical legal formalism); Cass R. Sunstein, Lochner's Legacy, 87 Colum. L. Rev. 873, 895 (1987) (noting analogous approach of early twentieth century formalism with Wechsler's use of legal process theory to critique the Warren Court).
} 
stantive aims, not to build and protect "reason" through procedural and institutional systems. ${ }^{284}$ What Arnold saw as the "theology" of the mature legal process approach-which included, for Henry Hart, counting the hours and minutes justices spent on each decision to see if they had sufficiently enabled "the maturing of collective thought" in their deliberative processes ${ }^{285}$ - was itself a culmination of the logical system whose coherence and consequences he had debated with Frankfurter. Viewed as part of a larger movement in American legal academia, first-generation administrative law scholarship was an early development in the building of a postwar, postrealist consensus around a particular vision of law and reason. Measured by their relative influence on legal doctrine and future scholarship, whether in the field of administrative law or in legal doctrines and legal academia generally, Arnold utterly lost the debate to Frankfurter, Hart, and the rest. But, as the next Part argues, aspects of his critique continue both to resonate in contemporary scholarship and to explain the idiosyncratic dynamics of administrative law.

\section{$\mathrm{V}$ \\ The "Logical System" in the Present: Continuing Faith, Crisis, and Dissent}

The approach offered by first-generation administrative law scholars, which was challenged by Arnold, successfully established a long-lasting conceptual system to help understand the role of law and legal institutions in the administrative state. Its concerns with administrative discretion and judicial review continue to structure and suffuse administrative law scholarship, curriculum, and doctrine. At the same time, the field regularly suffers through periods of crisis and self-examination due, in part, to the external political pressures placed on administrative agencies and their regulatory practices and to the insights of interdisciplinary scholarship that test some of administrative law's foundations.

284 Arnold thereby anticipated arguments that critics from fields as diverse as law and economics and critical legal studies would later employ against the legal process approach. For summaries of this criticism, see Eskridge \& Frickey, Historical and Critical Introduction, supra note 248, at cxviii-cxxv; Edward L. Rubin, The New Legal Process, the Synthesis of Discourse, and the Microanalysis of Institutions, 109 HarV. L. Rev. 1393, 1398-1402 (1996).

285 See Hart, supra note 254, at 86, 94, 100. 
This Part performs two roles: first, to update the Article's narrative beyond the 1930s and into the present; and second, to suggest both the strengths and weaknesses of the logical system whose development Arnold identified and decried. I posit that most legal academic challenges to the legitimacy and regulatory practices of administrative agencies and to the way in which the subject is studied, taught, and practiced arise from within the dynamic of institutional competence and judicial review that was found and furthered by first-generation scholars. Moreover, the frustration that these challenges represent is often resolved-to the extent that it is resolved at all-within the same dynamic. To challenge the dynamic itself, a project that some recent scholarship has undertaken, is to return to Arnold's project: first, resist or disrupt the presumptions of a comprehensive logical system built upon procedure; and second, embrace instead an explicit project of using a general administrative law to produce optimal regulatory practices rather than the most logical administrative and legal processes.

As much epilogue as argument, this Part does not offer a solution to the cycle of regulatory frustrations and endless debates that administrative law's logical system generates. Instead, it draws connections between the system as it was identified by first-generation scholars and as it currently exists. Looking first at continuity across time in administrative law scholarship, I argue that even though the faith that early scholars placed in agency competence and expertise diminished during the postwar period (both among first-generation scholars themselves and their successors), the field of administrative law has nevertheless remained in thrall to the logical system that the early scholars developed. We can see this at work not only in scholarship, but also in the continuity between current and early administrative law casebooks, where themes and structures developed in the earliest administrative law curricula continue to dominate the classroom. Second, I discuss how the approach originally developed by first-generation scholarship remains at the core of administrative law doctrine by analyzing the logic underlying the Administrative Procedure Act, the landmark administrative law decisions in the post-APA era, and the period during the 1970s in which courts and Congress expanded the rights of representation and participation among interested groups and individuals. Finally, I identify continuities between Arnold's opposition to first- 
generation scholarship and contemporary scholars' dissent to the current doctrines and practices of administrative law. This historical continuity confirms Arnold's insights regarding both the symbolic core of administrative law's logical system and the limits that this core places on how, and how much, any effort to reconfigure the system can succeed.

\section{A. Systemic Continuity in Theory and Teaching}

To claim historical continuity between the administrative law theory of the mid-1930s and the administrative law theory of seventy years later seems absurd on its face. The intervening decades have witnessed passage of the Administrative Procedure Act; a vast expansion of the number, type, and province of regulatory agencies; wide recognition of the administrative state's legal legitimacy; and, over the past three decades, recurrent calls for the dismantling of the federal regulatory apparatus. ${ }^{286}$ But at the same time, viewed from the abstract level of the logical system that first-generation administrative law scholars advocated, the field has been remarkably settled. A recent definition of administrative law by one of the field's most important theorists would look quite familiar to scholars of the 1930s:

[Administrative] law defines the structural position of administrative agencies within the governmental system, specifies the decisional procedures those agencies must follow, and determines the availability and scope of review of their actions by the independent judiciary. It furnishes common principles and procedures that cut horizontally across the many different substantive fields of administration and regulation. ${ }^{287}$

Although perhaps more settled and less prosaic, this contemporary definition corresponds to Landis' call more than six decades earlier for a supremacy of law over the administrative process that would provide a constitutional check on the actions of the congressional and executive branches as well as essential oversight of agency behavior. ${ }^{288}$

Administrative law scholarship often claims to be on the verge of breaking free from its early moorings. Three of the most vocal proponents of administrative agencies during the New Deal, then-Justice Frankfurter and his former students Louis Jaffe and

286 For an overview of this history, see Rabin, supra note 3, at 1262-1315.

287 Richard B. Stewart, Administrative Law in the Twenty-First Century, 78 N.Y.U.

L. REv. 437, 438 (2003).

288 See supra notes 91-94. 
James Landis, seemed to abandon their faith in administrative agencies in the decades following World War II and to lead a shift toward more thorough external checks on agencies' regulatory discretion. ${ }^{289}$ Justice Frankfurter, in his decision for the Court in $N L R B$ v. Universal Camera, claimed to recognize a political "mood" 290 in favor of enhanced judicial scrutiny of agency action in the Taft-Hartley Act's language requiring the NLRB's findings of fact to be supported "by substantial evidence on the record considered as a whole." 291 In his 1965 book Judicial Control of Administrative Action, Louis Jaffe denounced "judicial self-deprecation and abdication" of agency oversight. ${ }^{292}$ And in the 1960 report to President-Elect Kennedy on administrative practice and procedures from the commission he chaired, Landis proposed means to increase executive control over the federal regulatory bureaucracy. ${ }^{293}$ Distrusting agencies and their newly

${ }^{289}$ See HorwITZ, supra note 5, at 235-40. The precise periodization of this shift is the subject of some dispute. But whether this shift occurred immediately following World War II, over the course of the first two decades after the war, or later is largely irrelevant for purposes of my argument. See Thomas W. Merrill, Capture Theory and the Courts: 1967-1983, 72 CHI.-KENT L. REv. 1039 (1997) (asserting that the shift away from New Deal-era deference to agencies occurred in the 1970s); Daniel B. Rodriguez, Jaffe's Law: An Essay on the Intellectual Underpinnings of Modern Administrative Law Theory, 72 CHI.-KENT L. REV. 1159, 1163 (1997) (asserting that the shift occurred in the 1950s and 1960s); Reuel E. Schiller, Reining in the Administrative State: World War II and the Decline of Expert Administration, in Total War and the LaW: The American Home Front in World War II 185 (Daniel R. Ernst \& Victor Jew eds., 2002) (asserting that the shift began immediately following World War II).

290340 U.S. 474, 487 (1951).

$291 \mathrm{Id}$. at 491. This seemed to mark a change from Frankfurter's earliest administrative law decisions for the Court. In FCC v. Pottsville Broadcasting Co., for example, he used the familiar trope of judicial restraint and proper institutional roles and competencies to explain the limits of judicial review of agency decision making:

$[\mathrm{T}]$ he laws under which ... agencies operate prescribe the fundamentals of fair play. They require that interested parties be afforded an opportunity for hearing and that judgment must express a reasoned conclusion. But to assimilate the relation of these administrative bodies and the courts to the relationship between lower and upper courts is to disregard the origin and purposes of the movement for administrative regulation and at the same time to disregard the traditional scope, however far-reaching, of the judicial process. Unless these vital differentiations between the functions of judicial and administrative tribunals are observed, courts will stray outside their province and read the laws of Congress through the distorting lenses of inapplicable legal doctrine.

309 U.S. 134, 143-44 (1940).

292 Louis L. Jaffe, Judicial Control of Administrative Action 344 (1965).

293 Staff of Subcomm. on Administrative Practice and Procedure to the Senate Comm. on the Judiciary, 86th Cong., Report on Regulatory Agen. 
developed faith in judicial and other external checks on agency discretion, these leading first-generation scholars and others in the postwar period emphasized that, in Jaffe's words, "[t]he availability of judicial review is the necessary condition, psychologically if not logically, of a system of administrative power which purports to be legitimate, or legally valid." ${ }^{294}$ Indeed, Jaffe went so far as practically to denounce Landis and The Administrative Process in an article published after Landis's death, arguing that the hopes placed by New Deal advocates in administrative expertise and large federal regulatory agencies could only last as long as the New Deal's historical peculiarity. ${ }^{295}$ Similarly, in his report to Kennedy, Landis famously expressed his own frustration with the administrative state by excoriating regulatory agency performance and by proposing significant reforms. ${ }^{296}$ Within twenty-five years of leading the effort to establish a modern vision of administrative law, these stalwarts of the first generation seemed to repudiate their earlier conceptions of the administrative process.

However, as Arnold's critique of the first generation's "logical system" demonstrates, they may have lost faith in what they perceived to be the excesses of the New Deal regulatory state, but they continued to presume the stability of an underlying system of administrative law and process. Unlike Arnold, first-generation scholars did not want to dispense with or radically reframe the role of judicial review and, despite their abiding faith in agency expertise, they constructed a system of institutional tasks and competencies that included loose but still prevalent checks and balances. ${ }^{297}$ In fact, when the early work of first-generation scholars is remembered correctly, their later work does not appear to mark a loss of faith in the administrative process. Justice Frankfurter's decisions continued to focus on jurisdictional issues

Cies to the President-Elect (Comm. Print 1960) (written by James M. Landis) [hereinafter LANDIS REPORT].

294 JAFFe, supra note 292 , at 320.

295 See Louis L. Jaffe, James Landis and the Administrative Process, 78 HARv. L. REv. 319, 321-24 (1964).

296 See LANDis RePORT, supra note 293; see generally ThOMAs K. MCCRAW, Prophets of Regulation 206-07, 219-21 (1984) (discussing Landis RePORT, supra note 293).

${ }^{297}$ See supra text accompanying notes 53-59; cf. John F. Duffy, The FCC and the Patent System: Progressive Ideals, Jacksonian Realism, and the Technology of Regulation, 71 U. Colo. L. Rev. 1071, 1114-17 (2000) (characterizing New Deal supporters like Landis as embracing a vision of unfettered agencies). 
that restrained judicial intervention into the administrative process, ${ }^{298}$ while his opinion in Universal Camera merely sought to reflect and implement a change in legislative direction, thereby enforcing the wishes of the legislative institution. ${ }^{299}$ As a justice, his administrative law decisions sought to strike a balance between the integrity of the administrative process and the integrity of the lower federal courts. ${ }^{300}$ Jaffe himself noted in an analysis of Frankfurter's judicial decisions on administrative law that the jurist's "point of view" toward the field that he developed as an academic did not alter in its generalities, though its specific doctrinal patterns became "less pronounced [and] their application more flexible." 301

Frankfurter's disciples shared his views. Jaffe did not seek a radical change to the administrative process or the field of administrative law in the 1950s; instead, he suggested that faith in the absolute and necessary expertise of agencies was misplaced, and although no formula could perfectly check administrative discretion, judicial review was especially important "to curb and correct administrative distortion, to substitute the broad for the narrow bureaucratic view." 302 Nor did Landis' report present a radically different vision of the dynamics of administrative law despite his greatly increased suspicion of administrative discretion. ${ }^{303}$ Rather, he proposed incremental, structural solutions to increase presidential oversight and efforts to recruit better agency personnel. ${ }^{304}$ The logical system Frankfurter, Landis, and Jaffe advocated was sufficiently flexible to allow them to remain committed to its dynamic even as they advocated adjustments to its precise workings. If agencies were less expert and objective than they had previously appeared to the leaders of the first generation, then other competent institutions, particularly the judici-

\footnotetext{
298 Bernard Schwartz, The Administrative World of Mr. Justice Frankfurter, 59 YALE L.J. 1228, 1256 (1950).

299 For a thorough analysis of how Universal Camera fits within Frankfurter's evolving but consistent theory of administrative law, see Alfred S. Neely, Justice Frankfurter, Universal Camera and a Jurisprudence of Judicial Review of Administrative Action, 25 U. TOL. L. REv. 1 (1994).

300 Nathaniel L. Nathanson, Mr. Justice Frankfurter and Administrative Law, 67 YALE L.J. 240, 264 (1957).

301 Louis L. Jaffe, Adventures in Administrative Law, in Felix Frankfurter: The Judge 206, 206 (Wallace Mendelson ed., 1964).

302 JAFFE, supra note 292, at 26.

303 See LANDis Report, supra note 293, at 1-3.

${ }^{304}$ See id. at 66-68, 83-87.
} 
ary, could reform agency procedure and organization by tightening the reins and heightening their scrutiny of agenciesall without calling the system itself into question.

In their structure and focus, contemporary administrative law casebooks show a similar continuity. They are not significantly distinct from the first great modern administrative law casebook, Walter Gellhorn's first text ${ }^{305}$ (published in 1940), which moved from early chapters introducing the administrative state through the structural constitutional issues of the separation and delegation of powers. Gellhorn used the bulk of the book's text to discuss common law and pre-APA statutory efforts to define fair administrative procedures before concluding the casebook by focusing on judicial control over administrative determination. Although sprinkled with significant amounts of commentary on constitutional issues (including an extended excerpt from an Arnold article on the symbolic differences between judges and bureaucrats ${ }^{306}$ ), the Gellhorn casebook used a traditional case- and court-centered approach. Contemporary casebooks, even when they present significant amounts of theoretical and substantive background material in an introductory chapter to orient students to the administrative process, continue to take a court-centered approach that revolves around the role of judicial review and relies upon appellate decisions to illustrate and explain the relative institutional roles of administrative agencies and the three governmental branches. ${ }^{307}$ They still focus as well on procedural issues and on administrative discretion. ${ }^{308}$ The most significant departure from the current pedagogical norm are

305 See GellHoRn, supra note 72.

306 See id. at 147-52 (excerpting Arnold, Role, supra note 219, at 624-31).

307 See, e.g., Ronald A. Cass et al., Administrative Law: Cases and MATERIALS (4th ed. 2002) (presenting materials in three parts: "Institutional Framework," with one chapter on the nature and functions of agencies and two chapters on judicial review; "Administrative Functions," with chapters on policy formation, adjudication, enforcement, and licensing; and "Indirect Controls," with chapters on liability and public access); Jerry L. Mashaw et al., Administrative Law: The American Public System (5th ed. 2003) (following an extended introduction to administrative law, separate chapters focusing on how the legislature and executive supervise agencies, how agencies adjudicate, make rules, and gather and disperse information, and then how courts review suits to challenge administrative action); STRAuSS ET AL., supra note 74 (following an introduction to administrative law and a chapter on agencies' position within the "structural constitution," four chapters on administrative procedure and open government and then three chapters on judicial review).

308 See, e.g., STRAUSS ET AL., supra note 74, at iv (describing administrative law course and casebook as a body of judicially reviewable procedural requirements and 
casebooks that focus separately on administrative procedure in certain specific areas of substantive regulation and emphasize more clearly the nature and purpose of agencies' regulatory mandates. $^{309}$ But they largely reconfigure the traditional emphasis on judicial review by considering it on an agency-by-agency basis and by bracketing the substantive regulatory material in discrete, early sections. ${ }^{310}$ Thus, the substance and pedagogy of administrative law as an academic field reveals the extent to which the institution- and procedure-focused approach of first-generation scholarship remains dominant.

\section{B. Systemic Continuity in Doctrine}

The same continuity is apparent in the legal doctrines of administrative law. The most significant change in administrative law doctrine since the 1930 s is the Administrative Procedure Act ${ }^{311}$ whose passage in 1946 followed more than a decade of legislative efforts to constrain and legitimate administrative agencies. $^{312}$ The literature on the APA's history is vast and diverse and includes accounts that cast the APA as a historic triumph of the modern, progressive state, ${ }^{313}$ as a compromise among competing interests ${ }^{314}$ and between alternative constitutional theories, ${ }^{315}$ and as a partisan effort by Democrats to consolidate political and institutional gains won during the New Deal. ${ }^{316}$ But

concerns with efforts to control administration by the separate spheres of government).

309 See, e.g. , BREYER ET AL., supra note 4 (including an extensive introduction to regulation, a focus on regulatory substance and individual agencies, and an extensive section on alternatives to agency-based regulation).

$310 \mathrm{See}$, e.g., id. (focusing ultimately on judicial review and on using appellate decisions for teaching materials); see also Jerry L. Mashaw, Explaining Administrative Process: Normative, Positive, and Critical Stories of Legal Development, 6 J. L. ECON. \& ORG. 267, 268-69 (special issue 1990) (criticizing these casebooks' claims to dissent from the prevailing approach to administrative law, insofar as they too are "functionalist, procedural idealists" that illustrate the procedure- and structure-obsession of administrative law teaching and theory because of their failure to explain how substantive-specific procedure is generated and sustained).

311 Pub. L. No. 79-404, 60 Stat. 237, 240-43 (1946) (codified as amended in scattered sections of 5 U.S.C.).

312 See Shepherd, supra note 6.

313 See Walter Gellhorn, The Administrative Procedure Act: The Beginnings, 72

VA. L. Rev. 219 (1986).

314 See sources cited supra note 6.

315 See WHITE, supra note 4, at 116-27.

316 See McNollgast, The Political Origins of the Administrative Procedure Act, 15 J.L. ECON. \& ORG. 180, 182-83 (1999). 
whatever the story of its derivation, the APA fits neatly within the general approach of first-generation administrative law scholarship by offering a procedural fix to the challenge of controlling and legitimating a growing federal government. It did so by outlining a general, default administrative process. Under the compromise embedded within the APA's distinction between adjudication and rulemaking and developed further in judicial common law, agencies making formal adjudicative decisions follow strict procedures required to protect individual parties, while agencies engaged in rulemaking for which a relevant statute does not specifically require formal, on-the-record rulemaking, can proceed relatively unburdened by formal procedural requirements. ${ }^{317}$

Ultimately, the APA established a presumption of judicial review of agency action in all cases. ${ }^{318}$ This statutory basis for judicial review requires courts to employ relatively vague, openended standards. Actions that are "arbitrary, capricious [or] an abuse of discretion" or "unsupported by substantial evidence" are to be set aside. ${ }^{319}$ These standards are consistent with the general drift that the Court had been taking in the years prior to passage of the APA toward a largely deferential but slightly more intense review. ${ }^{320}$ The Supreme Court quickly perceived the statute as, above all, an institutional and procedural settlement that established "a formula upon which opposing social and political forces have come to rest." 321

Thus, "administrative law" encompasses a general two-step procedure: an administrative process, operated within administrative agencies on the basis of legislative direction, develops, implements, and enforces policy; and then judicial review, undertaken within a constitutionally and prudentially limited le-

317 See Administrative Procedure Act, Pub. L. No. 79-404, $\S 4,5,7,10$ (a), 60 Stat. 237, 240-43 (1946) (codified as amended in scattered sections of 5 U.S.C.); U.S. Department of Justice, Atrorney General's Manual on the Administrative Procedure Act 14-15 (1947); Ronald A Cass, Administrative Law: Cases and Materials 416-20 (4th ed. 2002); Martin Shapiro, Who Guards THE Guardians? 44-46 (1988).

318 See Administrative Procedure Act, Pub. L. No. 79-404, § 10(a), 60 Stat. 237, 243 (1946) (codified as amended in scattered sections of 5 U.S.C.).

319 See id. $\$ 10(\mathrm{e}), 60$ Stat. at 243-44.

320 See Reuel E. Schiller, Enlarging the Administrative Polity: Administrative Law and the Changing Definition of Pluralism, 1945-1970, 53 V AND. L. REV. 1389, 141719 (2000) (citing Addison v. Holly Hill Fruit Prods. Inc., 322 U.S. 607 (1944); Skidmore v. Swift \& Co., 323 U.S. 134 (1944)).

321 Wong Yang Sung v. McGrath, 339 U.S. 33, 40 (1950). 
gal process, serves as an ex post check on agency action by a separate institution. Settling institutional responsibilities, as well as providing an administrative process and a basis and standard for judicial review, the APA solidified a basic logic in administrative law doctrine of institutional roles and administrative procedures. $^{322}$ This logic, in turn, serves both to legitimate and constrain the administrative state ${ }^{323}$ precisely in the manner that first-generation scholars advocated.

The Supreme Court has employed this logical system in its landmark administrative law cases over the past thirty years. Consider, for example, Vermont Yankee Nuclear Power Corp. $v$. Natural Resources Defense Council, Inc. ${ }^{324}$ and Chevron U.S.A., Inc. v. Natural Resources Defense Council, Inc. ${ }^{325}$ two of the most significant, oft-cited administrative law decisions that the Supreme Court has issued over the past three decades. ${ }^{326}$ In Vermont Yankee, in which it admonished lower courts against imposing procedural requirements on agencies that were not mandated by Congress, the Court explicitly identified the proper functions of the various institutions relevant to regulation generally and the regulation of nuclear power specifically: ${ }^{327}$ Congress and the states resolve the fundamental policy questions relating to regulation; agencies carry out these policies; Congress and agencies develop the procedures that agencies use to carry out the policies; and courts must "perform their appointed function" and make certain merely that the agency came to a fully informed and well-considered decision. ${ }^{328}$ The same logic underlies the two-step test for the judicial review of an agency's statutory construction that the Court elaborated in Chevron. ${ }^{329}$ In each step-first, evaluating whether Congress provided an unambiguous statutory command, and second, in the case of statutory am-

322 See Stewart, supra note 2, at 1679-81.

323 See Verkuil, supra note 43, at 278-79.

324435 U.S. 519 (1978).

325467 U.S. 837 (1984).

326 See STRAUSs ET AL., supra note 74, at 1033 (noting Chevron's position as the most frequently cited administrative law decision by federal circuit courts of appeals); MAshaw ET AL., supra note 307, at 556 ("Vermont Yankee . . provoked a large secondary literature.").

327 Vermont Yankee, 435 U.S. at 549 (1978).

328 Id. at 557-58; see Peter L. Strauss, From Expertise to Politics: The Transformation of American Rulemaking, 31 W AKE FOREST L. REv. 745, 757 (1996) (characterizing Vermont Yankee as reiterating "the properly institutional character of rulemaking").

329 Chevron, 467 U.S. at $843-45$. 
biguity, considering whether the agency's construction was permissible - the issue before a court reviewing a challenge to an agency's interpretation is whether the agency performed its role properly within the bounds of its own authority. The Court thereby limited, without eliminating, judicial review by parceling out institutional functions and by identifying the limits of institutional purview. Courts cannot claim expertise in fields of policy development reserved to Congress and executive agencies; still, courts retain the necessary authority to check statutory interpretations that are unreasonable and contrary to legislative intent. ${ }^{330}$ Both Vermont Yankee and Chevron reiterated and employed the common sense of institutional settlement and competence, separate functions, and the limited but powerful backstop of judicial review. ${ }^{331}$ Significantly, the decisions were unanimous, reflecting a sense that, at least for the Court, their holdings and logic were uncontroversial.

Admittedly, this consistency between contemporary doctrine and first-generation administrative law has occurred at a high level of abstraction. Doctrine has not remained static during this period-especially the standards and role of judicial review. Most significantly, as Richard Stewart famously identified in 1975 , the early 1970 s witnessed at least a temporary breakdown of what he termed the "traditional model" of judicial review and

330 See id. at 843 n.9, 865-66; cf. Cass R. Sunstein, Law and Administration After Chevron, 90 Colum. L. Rev. 2071, 2085-88 (1990) (explaining Chevron as a "valueladen judgment about comparative competence, undertaken in light of the regulatory structure and applicable constitutional considerations").

331 But see Werhan, supra note 96, at 590-97 (arguing that Chevron and the general drift of the Court's administrative law jurisprudence has marked a radical departure away from a modern administrative law influenced by legal process theory and toward a formalist, "neoclassical" revival). As I have noted elsewhere in this Article, see supra notes 247 and 267, where Werhan sees historical shifts, I see deeper continuity. Specifically, first-generation administrative law scholars developed structural notions of institutional competency and the significance of a limited but significant judicial review that legal process theory later adopted as core principles. But because of the specific political exigency of supporting the New Deal, firstgeneration scholars had significantly less to say about statutory interpretation, preferring instead to emphasize strict limits on the judiciary's role at the same time they invoked the importance of judicial review. See text accompanying supra Parts I.B and I.C. When the history of administrative law theory is viewed this way, Chevron and Vermont Yankee do not appear as historical anomalies, and they are ultimately not such radical departures from the interest representation approach insofar as the approaches share a structural vision and logic as to the relative roles of agencies and courts. To the extent that they differ, Chevron and Vermont Yankee in fact appear more consistent with the traditions established in the beginnings of the modern era of administrative law than with the heyday of the interest representation approach. 
formal procedures and the emergence of a largely court-imposed, pluralist model of administrative process in which agencies were (and to a great extent continue to be) required to consider a fair representation of affected interests in their rulemaking procedures. ${ }^{332}$ Related statutory efforts to open the records and meetings of the administrative process to the public became law in the 1960s and 1970s and further expanded the participatory and open aspects included in the original APA. ${ }^{333}$

But this shift, though it affected agency operations and judicial review, operates within administrative law's familiar core commitment to "a common social value in legitimating, through controlling rules and procedures, the exercise of power over private interests by officials not otherwise formally accountable"334 -ultimate enforcement of which was vested in the judiciary. Moreover, the shift's momentum quickly abated, in part for reasons Stewart identified; not only were the requirements costly and burdensome to agencies, but the enhanced role of the judiciary appeared to involve a "troubling aggrandisement [sic] of judicial power" and threatened to enable the kind of unchecked judicial branch that the first-generation administrative law scholars, and New Deal proponents generally, abhorred. ${ }^{335}$ But even viewed from Arnold's perspective, the interest representation model's threat to remake the system of administrative law did not shake the field's foundations. Expanded participation and representation rights as well as marginally enhanced standards of judicial review are largely procedural fixes to political legitimacy crises, creating statutory rights and imposing common law changes on administrative procedures without directly affecting the systematic logic of the administrative state. They do not approach the

332 See Stewart, supra note 2, at 1669-75.

333 These include the statute imposing record disclosure requirements on agencies, the Freedom of Information Act (which became law in 1966 and was the subject of important amendments in 1974); the statute imposing open meeting requirements, the Government in the Sunshine Act (enacted in 1976); and the statute imposing access requirements on advisory committees formed by federal agencies, the Federal Advisory Committee Act (enacted in 1972). See Freedom of Information Act, Pub. L. No. 89-497, 80 Stat. 250 (1966); Freedom of Information Act Amendments of 1974, Pub. L. No. 93-502, \$§ 1-3, 88 Stat. 1561, 1561-64 (codified as amended at 5 U.S.C. $\S 552(2000)$ ); Government in the Sunshine Act, Pub. L. No. 94-409, 90 Stat. 1241 (1976) (codified as amended at 5 U.S.C. \$ 552(b) (2000)); Federal Advisory Committee Act of 1972, Pub. L. No. 92-463, 86 Stat. 770 (codified as amended at 5 U.S.C. app. I (2000)).

334 Stewart, supra note 2, at 1671.

$335 \mathrm{Id}$. at $1802-03$. 
outer boundaries that Arnold proposed, in which courts programmatically join in the regulatory process or remove themselves from any control over it. Although representation and participation may have complicated and inhibited agency operations and judicial review, ${ }^{336}$ they have not significantly diminished administrative law's faith in procedure, institutional competencies, and legal-centrism; indeed, they have reinforced the assumption that procedural requirements placed upon agencies and enforced by judicial review lead to better substantive policy by opening the administrative process to greater and wider participation. ${ }^{337}$

\section{Continuity of Crisis and Dissent}

As it appears in contemporary casebooks and legal doctrine, administrative law may look relatively similar to the field as it emerged from the $1930 \mathrm{~s}$, but, at least with respect to administrative law theory, this continuity should not be mistaken for ossification. As I noted earlier, administrative law as a body of doctrine and as an academic field has faced recurring political crises over allegations that agencies impose unfair or inefficient regulatory practices, are subject to capture by regulated industries or public interest groups, or are simply incompetent. ${ }^{338}$ As the first-generation scholars themselves demonstrated during the 1950 s, these bouts of frustration have forced the field to rethink at least some of its assumptions about agency discretion and judi-

336 See Jim Rossi, Participation Run Amok: The Costs of Mass Participation for Deliberative Agency Decisionmaking, 92 Nw. U. L. Rev. 173, 217-36 (1997); Schiller, supra note 320 , at $1450-52$.

337 This is clear in Judge Leventhal's decision in Greater Boston Television Corp. v. FCC, one of the landmark decisions of the D.C. Circuit's adoption of a procedural "hard look" review of agency action, where-despite engaging in what might have appeared to be a distinctly rigorous approach to judicial review-the court declared its continuing reliance on notions of institutional competence and limited judicial review that would be constrained by the court's role of evaluating agency action against legislative intent. See Greater Boston Television Corp. v. FCC, 444 F.2d 841, 851-52 (D.C. Cir. 1970). Moreover, hard look review, even when putatively substantive under the Supreme Court's State Farm decision, Motor Vehicle Mfrs. Ass'n of the U.S. v. State Farm Mut. Auto. Ins. Co., 463 U.S. 29 (1983), generally focuses on procedural, rather than substantive, defects in an agency's action. See Harold H. Bruff, Legislative Formality, Administrative Rationality, 63 TEx. L. REV. 207, 239 (1984) (noting that under "hard look" review, agencies tend to perform a "charade" of procedural sufficiency when they have already reached their substantive conclusions and that courts are "drawn to a subterfuge" of procedural defect when the essential issue underlying their remand of an agency decision is substantive).

338 See supra notes $2-3$ and accompanying text. 
cial review. Scholars find this crisis on display in numerous contexts: in the administrative state's failure to address ongoing social and economic crises effectively; ${ }^{339}$ in federal agencies' lack of public legitimacy, notwithstanding the abundance of administrative and legal checks on their actions; ${ }^{340}$ in the ideological application of open-ended administrative law doctrine by courts, especially among judges on the D.C. Circuit; $;{ }^{341}$ and, looking selfreflexively, in the lack of a discernible subject matter, approach, and individual identity in administrative law scholarship itself. ${ }^{342}$

At least some of these issues may be in part symptomatic of scholars' frustration with administrative law's proceduralist and institutionalist core. Addressing systemic concerns-such as widespread regulatory failure, agency capture, or, more worrisome, a lack of legitimacy for the federal administrative state as a whole-by returning endlessly to issues of procedure and the mechanics of judicial review seems a hopeless and circular enterprise. In this context, we could read Arnold's critique as warning scholars, lawyers, and judges either to get in to the administrative state all the way or get out of the way. But whatever you do, Arnold cautioned, do not stand in its way.

Unsurprisingly, given the frustrating logic of the field, some contemporary critics have suggested more conceptually radical changes-changes that, by moving away from traditional conceptions of administrative law as doctrine and as an academic field, resemble Arnold's critique of the procedural and conceptual core of first-generation scholarship. A small sampling of such criticism reveals its parallels to Arnold's earlier dissent. As a system, some critics argue, administrative law is fatally flawed. It is excessively adversarial and legalistic in its approach to regulation, and it thereby imposes unnecessary and otherwise avoidable social and economic costs to the regulatory process. ${ }^{343}$ Its focus on judicial review invites courts to interfere in the administrative process, especially in rulemaking. ${ }^{344}$ It is based on a premodern

339 See Christopher Edley, Jr., The Governance Crisis, Legal Theory, and Political Ideology, 1991 DUKE L.J. 561, 563-64.

340 See BREYER ET AL., supra note 4, at 166-68.

341 See Richard J. Pierce, Jr., The Special Contributions of the D.C. Circuit to Administrative Law, 90 GEO. L.J. 779, 783-85 (2002); Richard L. Revesz, Environmental Regulation, Ideology, and the D.C. Circuit, 83 VA. L. REv. 1717, 1719 (1997).

342 See Thomas, supra note 24, at 76-77.

343 See Robert A. Kagan, Adversarial Legalism: The American Way of LAW 198-206 (2001).

344 See Frank B. Cross, Shattering the Fragile Case for Judicial Review of Rulemak- 
sensibility and understanding of the administrative state as quasilegislative and quasi-adjudicative, and it thereby misunderstands and impedes modern, instrumentally rational agency operations. ${ }^{345}$ And with its hierarchical, tightly structured system, it cannot reckon with the role that private entities increasingly play in public governance and the opportunities that this role offers for interdependent relationships between private and public realms. ${ }^{346}$ Similar criticism condemns administrative law as an academic field for its excessive focus on the judiciary, which renders it unable to consider the extent to which internal administrative processes operate outside the control of judicial review, ${ }^{347}$ as well as for its related failure to develop a theory of regulation that can account for the dynamics of regulatory practice and policy formation. ${ }^{348}$ Finally, the entire growing body of literature applying public choice and positive political theory to administrative agencies challenges the naiveté of first-generation scholarship. Far from a logical system of competent institutions with sufficient internal checks to protect the rule of law, the administrative state, public choice scholars argue, is composed largely of self-interested actors seeking to maximize individual and institutional capital. ${ }^{349}$ And far from being reasoned, objective means

ing, 85 VA. L. REV. 1243 (1999) (arguing that judicial review of administrative rulemaking is both unwise and likely unconstitutional); Martin Shapiro, APA: Past, Present, Future, 72 VA. L. REv. 447, 478-79 (1986) (warning against powerful judicial review because it discourages agency discretion and empowers judges to perform economic due process review of agency rulemaking).

345 See Edward Rubin, It's Time to Make the Administrative Procedure Act Administrative, 89 CORNELl L. REv. 95, 189-90 (2003); see also EDLEY, supra note 2 (complaining of the outdated judicial control of administrative agencies that arises from a "trichotomy" of adjudicative fairness, scientific expertise, and politics that correspond with judicial, executive, and legislative institutions, and concluding that this outdated control manifests itself in conceptual failings, incoherence, and poor governance).

346 See Freeman, supra note 2, at 545-50.

347 See, e.g., MASHAW, supra note 9 (noting that in the context of social security disability claims, the traditional conception of judicial review's role in administrative law is descriptively false, as most claims are considered and resolved internally without judicial oversight or appeal); Rabin, supra note 2, at 126-28, 132, 144-45 (criticizing the traditional administrative law approach for its judicial-centric approach that fails to consider the important internal administrative practices that affect the consequences of substantive regulatory programs).

348 See Steven P. Croley, Theories of Regulation: Incorporating the Administrative Process, 98 Colum. L. Rev. 1, 6 (1998); Susan Rose-Ackerman, Progressive Law and Economics-And the New Administrative Law, 98 YALE L.J. 341, 347 (1988); Stewart, supra note 2, at 1670-71 n.5.

349 The public choice literature is vast. For an excellent summary and critique, see Croley, supra note 348 , at $34-56$. 
to control discretion and legitimate agency action, administrative procedures, positive political theory scholars tell us, are merely means by which legislators protect their own political interests and those private interests that they represent. ${ }^{350}$

These are inherently functional critiques, asserting that no matter the symbolic value of a system built on conceptions of preconstituted, legitimating procedures and institutions, what may have once appeared to be a logical system now obstructs the administrative state from either achieving the goals set out by its political masters or realizing the potential benefits of its expert bureaucracy. Not all of these critics propose radical reform-indeed some, like the first-generation scholars who sought to reform the system in the 1950s, would merely rejigger judicial standards of review ${ }^{351}$ or invigorate structural constitutional doctrines ${ }^{352}$ - but all challenge what first-generation scholars took as an article of faith, namely, that administrative law is concerned solely with designing legal and administrative processes that will lead inexorably to legitimate and optimal regulatory results. These critics represent a trend toward focusing on substantive consequence rather than system, procedure, and form. ${ }^{353}$ They

350 See Matthew D. McCubbins et al., Structure and Process, Politics and Policy: Administrative Arrangements and the Political Control of Agencies, 75 VA. L. REV. 431 (1989); Matthew D. McCubbins et al., Administrative Procedures as Instruments of Political Control, 3 J.L. Econ. \& ORG. 243 (1987).

351 See, e.g., EDLEY, supra note 2, at 230-34 (calling for courts to review agency decisions based on norms of "sound governance"); William S. Jordan, III, Ossification Revisited: Does Arbitrary and Capricious Review Significantly Interfere with Agency Ability to Achieve Regulatory Goals through Informal Rulemaking?, 94 Nw. U. L. REV. 393, 445 (2000) (advocating partnership model of judiciary-agency relationship rather than hard look review of administrative rulemaking, but casting such partnership as "comparable to the professor's review of a major research paper" in which the reviewer is "demanding" and "prepared to make difficult judgments," but with the shared goal of creating "a well-reasoned product"); Shapiro, supra note 344 , at 467,491 (calling for broader agency discretion and less judicial imposition of the requirement that agencies engage in "synoptic" decision-making processes).

352 For example, public choice theorists have argued that structural constitutional fixes, such as an invigorated nondelegation doctrine, could fix legislative overdelegation to administrative agencies that lead to coercive, inefficient transfers from the public sector to private interest groups. See Peter H. Aranson et al., $A$ Theory of Legislative Delegation, 68 Cornell L. Rev. 1, $63-67$ (1982); Jonathan R. Macey, Transaction Costs and the Normative Elements of the Public Choice Model: An Application to Constitutional Theory, 74 VA. L. REV. 471, 513-18 (1988).

353 See Richard A. Posner, The Rise and Fall of Administrative Law, 72 CHI.KENT L. Rev. 953, 957 (1997) ("Administrative law scholarship has acquired . . . a more substantive, a more economic, and a more institutional cast. There is much more interest in what works, and much less in the forms and formalities of the administrative process except insofar as they shape consequences in the real world."). 
represent as well a skepticism about the successful articulation of a universal, overarching theory of administrative law. ${ }^{354}$ As such, these criticisms echo frustrations that Arnold first voiced-frustrations regarding how the first-generation scholars conceived of the administrative state as well as whether and how administrative law could legitimate and tame agencies. Reconsidering Arnold and the foundational efforts of first-generation scholarship reveals a clearer picture of the difficulties and stakes of administrative law reform.

\section{CONCLUSION}

In 1935, Arnold quipped that administrative law offered a "Redeemer" for a public in need of, but afraid of, a modern administrative state. ${ }^{355}$ In the intervening years, it has served that purpose for law professors who revere, obsess over, and complain about administrative law's emphasis on procedure, institutional competencies, and judicial review. Arnold correctly predicted both the success of that emphasis and the frustrations it would create. The failure of his proposals, which offered no logical system or symbolic substance to attract and inspire the field, also proves his point: for its own legitimacy, administrative law may need its logical system, regardless of that system's effects on regulatory functionality.

354 See Mark Seidenfeld, The Quixotic Quest for a "Unified" Theory of the Administrative State, Issues in Legal Scholarship, Article 2 (2005), at http://www. bepress.com/ils/iss6/art2; Sidney A. Shapiro, Pragmatic Administrative Law, Issues IN Legal Scholarship, Article 1 (2005), at http://www.bepress.com/ils/iss6/art1.

355 Arnold, Symbols, supra note 1, at 64. 